\title{
CAUSES OF THE PHENOMENON OF SCHOOL DROPOUT AMONG GIRLS AND ITS IMPACTS IN RURAL AREAS OF EL-AYAT DISTRICT, GIZA GOVERNORATE,EGYPT
}

\author{
(Received:20.6.2019)
}

\author{
By \\ G.M. A. El-shaer and M. Y. A. Radwan \\ Department of Rural Sociology, Faculty of Agriculture, Al-Azhar University, Cairo, Egypt
}

\begin{abstract}
The present research aimed to identify the Causes of the phenomenon of School Dropout among girls and its impacts; the reasons related to the girl herself, the social reasons, the economic reasons, the reasons related to the school environment, and determining the social, economic and psychological impact of the phenomenon; as well as respondents' proposals to overcome the phenomenon. This research was conducted on 140 respondents of householders from the villages of the sample, data were collected through a questionnaire during the months of November and December 2018. After that, data have been discharged and analyzed statistically; tables, percentage, simple correlation coefficient, Chi square, and average degree were used in the presentation and analysis of results. It was clear from the results that:The most important reasons of the phenomenon of girls' school dropout related to the girl were the weakness of the general health of the girl, the weakness of self-confidence, the sense of deprivation and oppression. The most important social reasons of the phenomenon of girls' school dropout were the presence of a suitable groom for the girl, the lack of importance of certificate and education, preferring males' education, frequent family problems and disputes, the death of the father or mother. The most important economic reasons of the phenomenon of girls' school dropout were the inability to spend on the girl to complete education, insufficient income to spend on the family, having many children, the lack of permanent work, and the girl work to help family in living. The most important reasons of the phenomenon of girls' school dropout related to the school environment were the repetition of school failure, the long distant of school to girls' houses, poor school facilities, lack of good treatment by teachers, classroom density, and lack of school activities. The most important social effects of the phenomenon of girls' school dropout were illiteracy, lack of awareness, early marriage, inability of girls to raise their children as necessary, many problems and family disputes, high divorce rates, lack of time value importance for the girl, lack of participation value importance for the girl.

The most important economic effects of the phenomenon of girls' school dropout were high child labor, rising unemployment, increasing the financial burden on the family. The most important psychological effects of the phenomenon of girls' school dropout: the girl's feeling of depression, her constant sense of anxiety, her sense of permanent disability, and feeling not belonging. There was a significant relationship between the educational statue of the respondents and their opinion about the importance degree of the social effects of the phenomenon of girls' school dropout. Also, there was a positive significant relationship between the number of family members' variable of the respondents and their opinion about the importance degree of the economic effects of the phenomenon of girls' school dropout. And, There was a significant relationship between the educational status of the respondents and their opinion about the importance degree of the psychological effects of the phenomenon of girls' school dropout. The most important proposals of the householders to overcome the phenomenon of girls' school dropout were: increasing financial support for families of dropouts, provide financial rewards for families that agree to return to school, increasing the awareness of rural families about the importance of family planning, increasing the awareness of rural families about the importance of educating girls, developing schools and increasing their numbers, and preventing physical and verbal punishment in schools.
\end{abstract}

Key words:School dropout girl's, education, educational inequality. 


\title{
أسباب ظاهرة تسرب الفتيات من التعليم والآثار المترتبة عليها بريف مركز العياط محافظة الجيزة \\ جمال محمد أحمد الشاعر - مصطفى يوسف أبوزيد رضوان \\ قسم الإجتماع الريفى بكلبة الزراعة - جامعة الأزهر - القاهرة - مصر
}

\begin{abstract}
ملخص من رئر

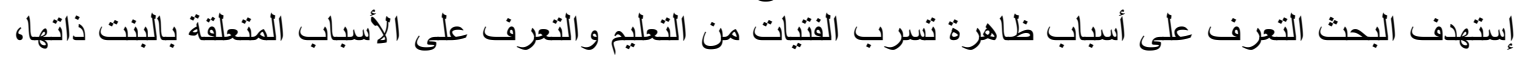

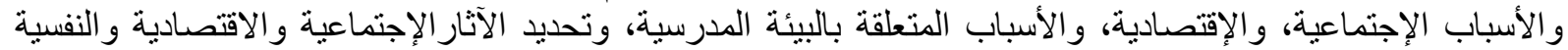

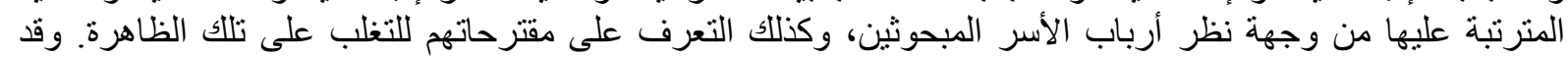

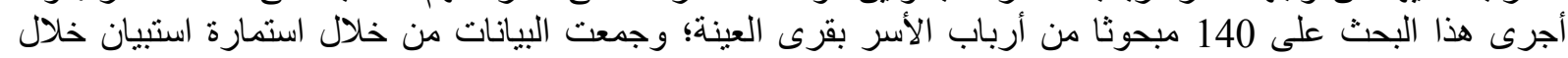

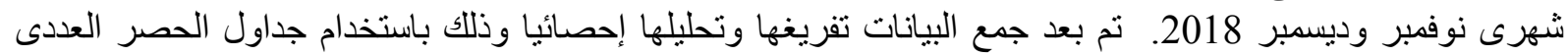

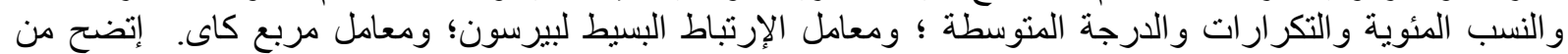

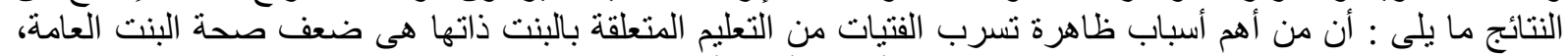

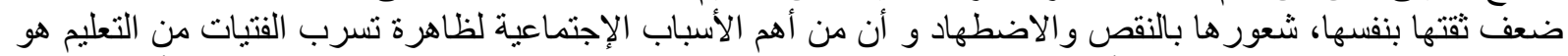

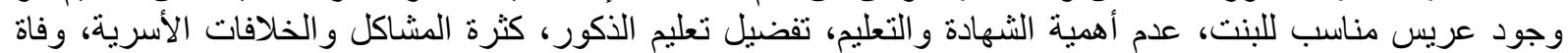

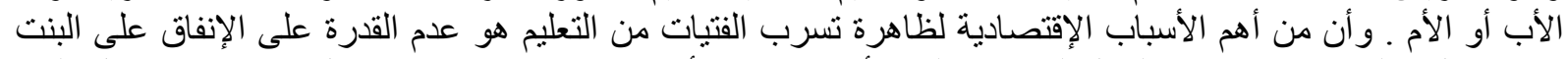

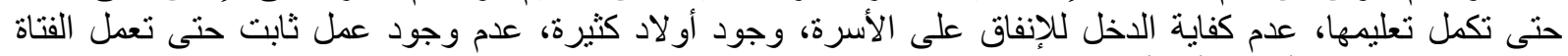

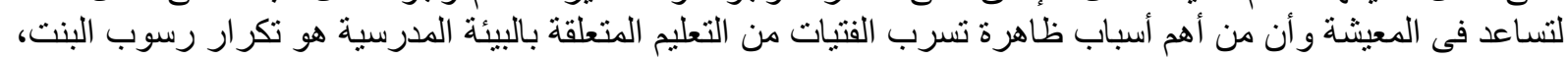

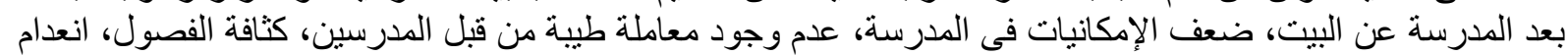

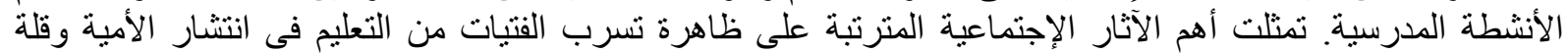

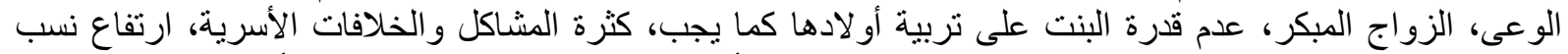

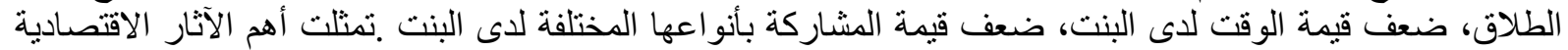

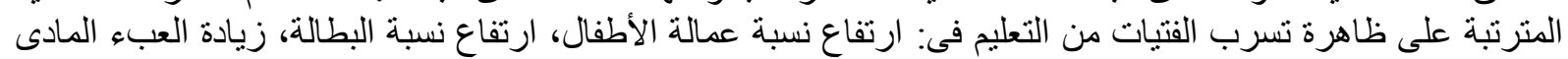

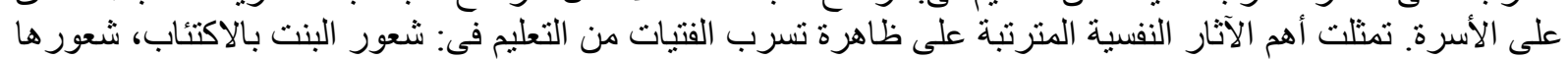

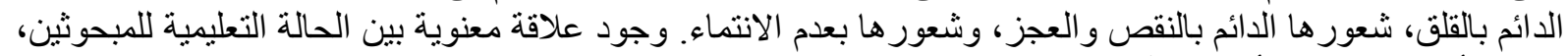

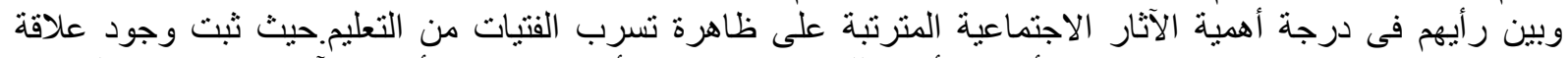

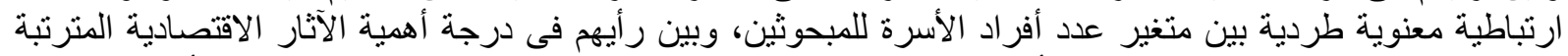

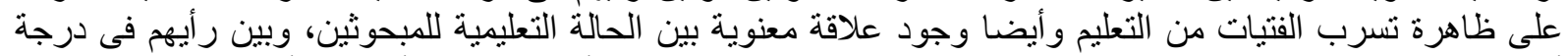

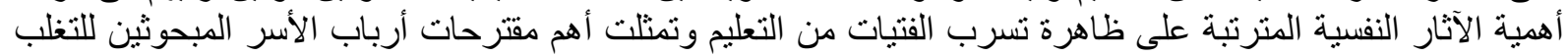

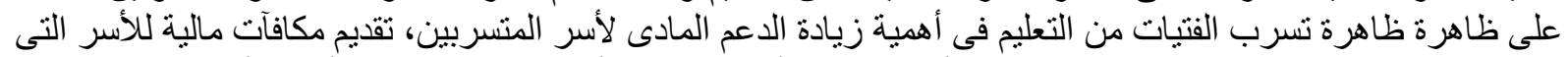

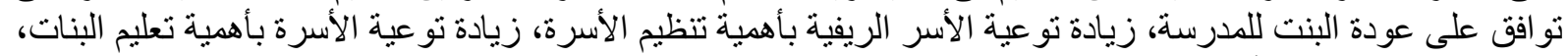

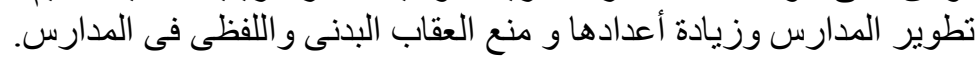

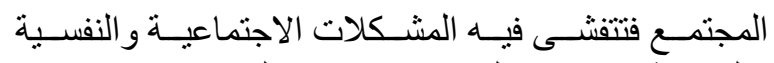

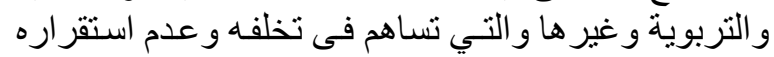

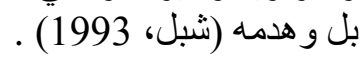

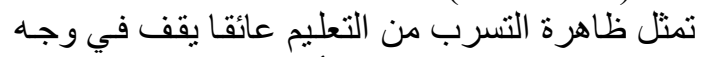

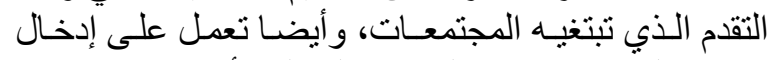

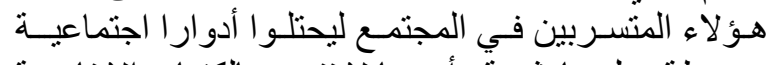

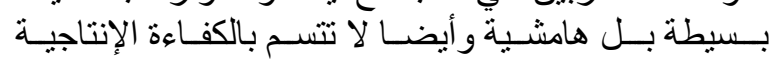

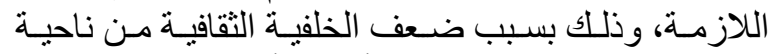

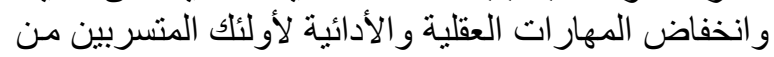
ناحية أخرى ( اسماعيل، 1998).

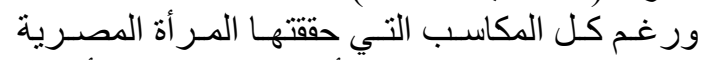

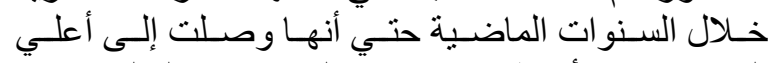

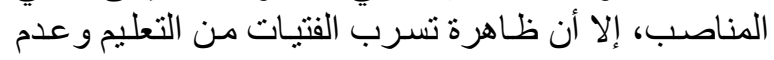

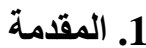

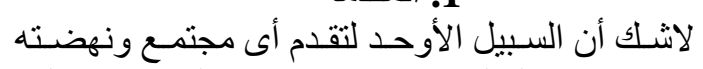

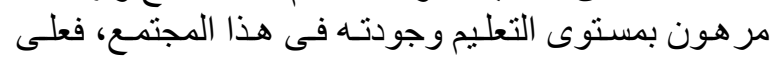

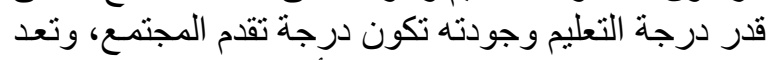

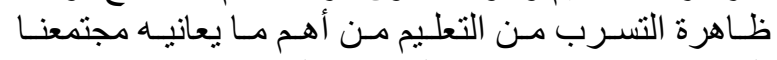

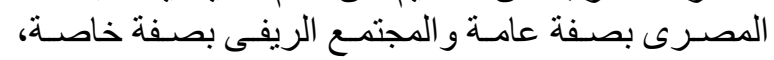

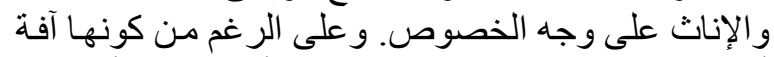

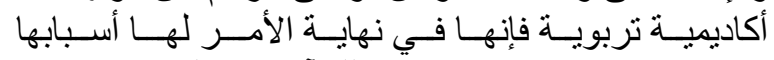

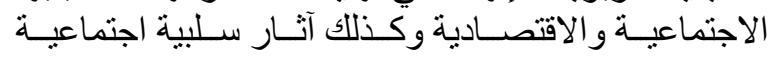

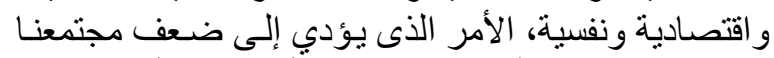

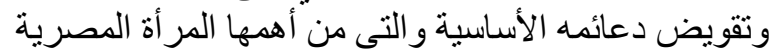

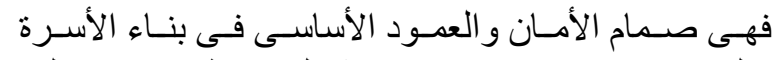

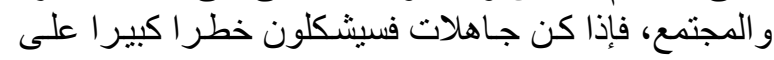




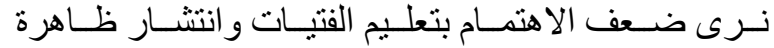
تسربهن من التعليم، وخاصة في الريف الريف

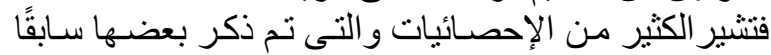

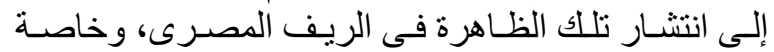

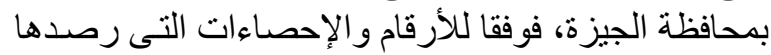

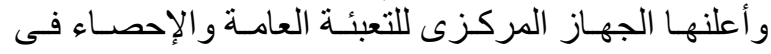

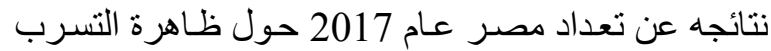

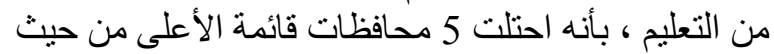
أكثر المتسربين من التعليم بها. حيث جاءت التهات مجافظة الجيزة

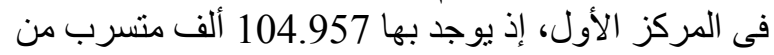

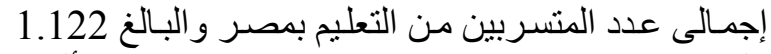

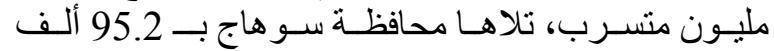
متسرب، واحتلت محافظـة أسوان المركز الثالث بـ 91.9

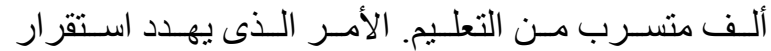

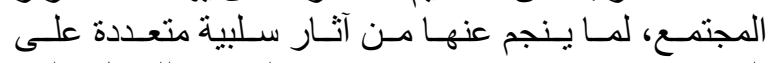

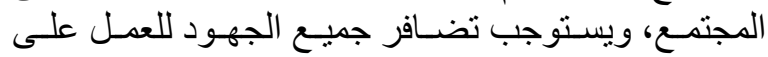

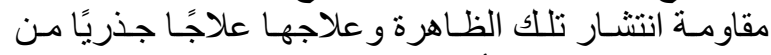

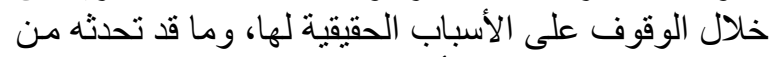
آثار سلبية على البنت و الأسرة و المجنمع.

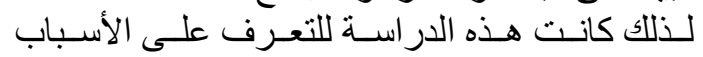

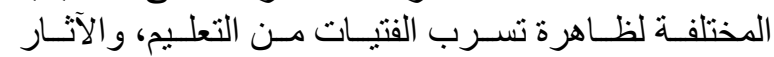

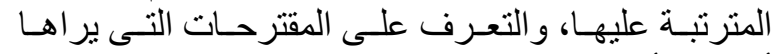
أرباب الأسر المبحوثين للتخلب على هذه الظاهرة.

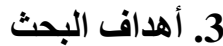

فى ضوء مشكلة البحث السـابق عرضهـا تحددت أهدافه

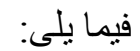

1- التعرف على على أسباب ظـاهرة تسرب الفتيـات من التعليم

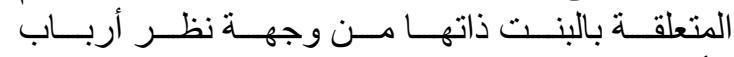
الأسر المبحوثين.

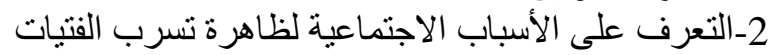
من التعليم من وجهة نظر الأرباب الأسر المبحوثين.

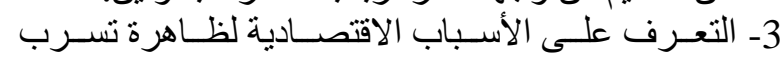

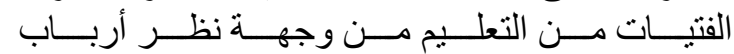

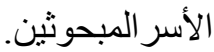

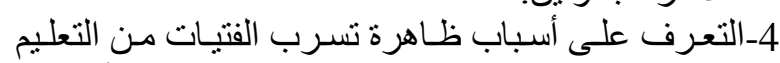

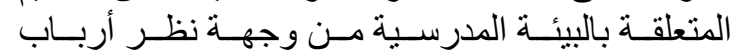
الأسر المبحوثين.

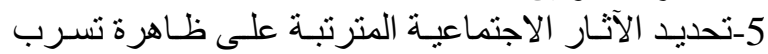

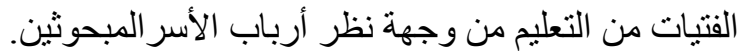

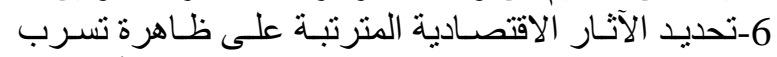

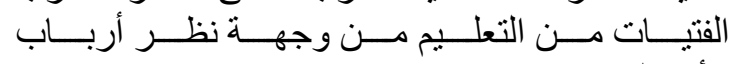
الأسر المبحوثين.

7-تحديد الآثار النفسية المترتبة على ظاهرة تسرب الفتيات

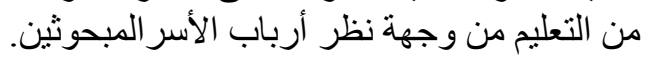

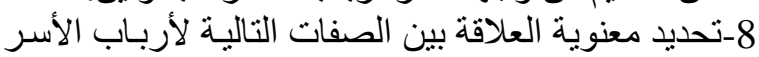

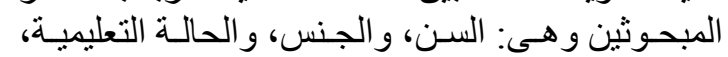

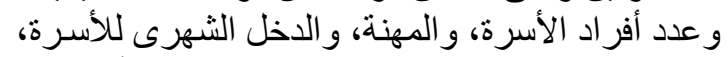

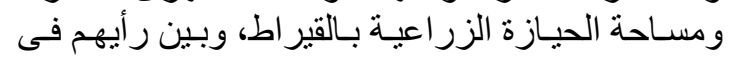

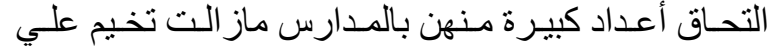

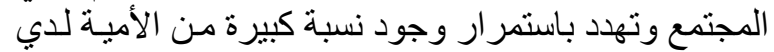
البنات، سيدات المستقبل ( السيد، 2002).

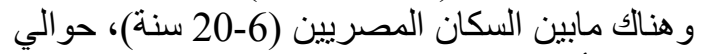

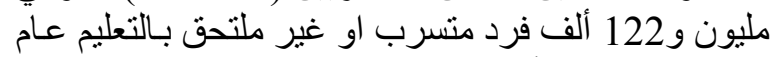

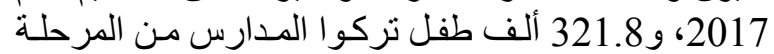

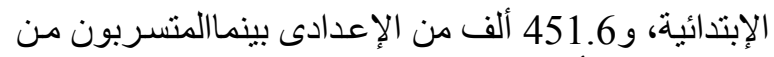

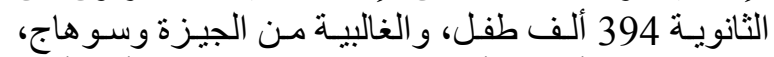

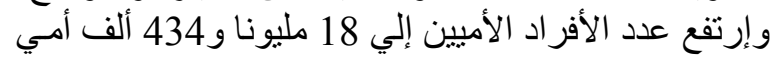

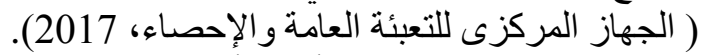

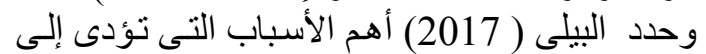

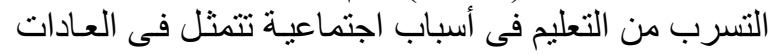

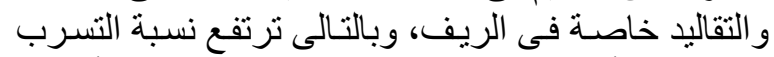

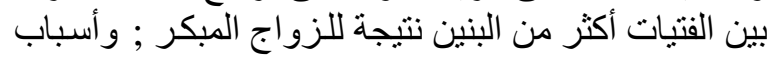

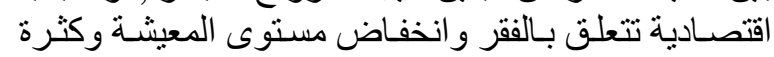

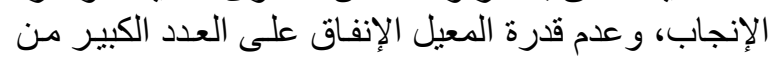

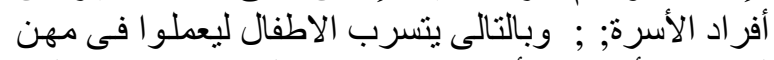

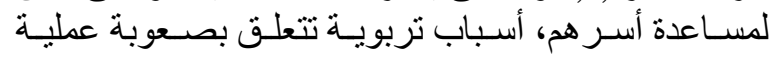

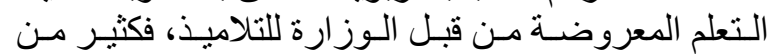

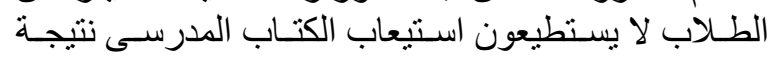

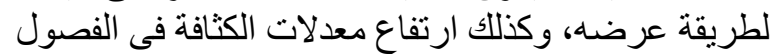

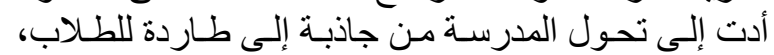

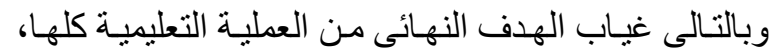

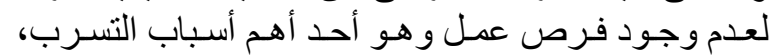

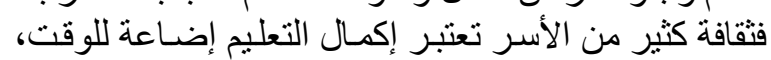

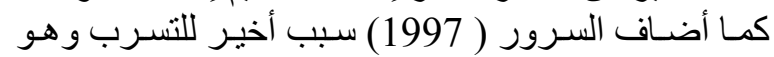

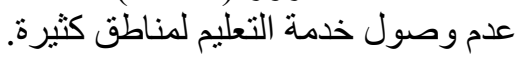

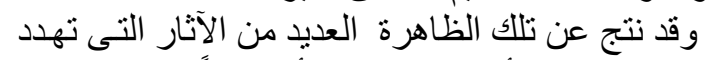

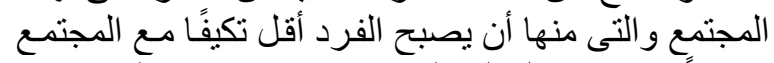

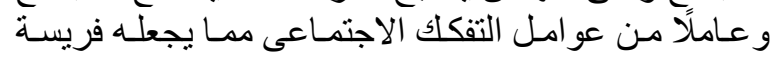

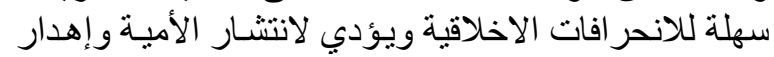

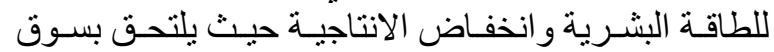

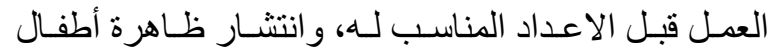

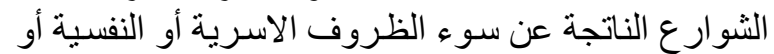
التعليمية، وتفاقم مشكلة عمالـة الأطفال أحد الآثار السلبية التبلية

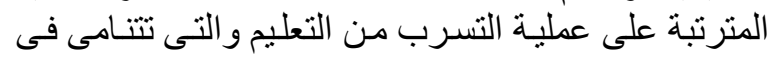

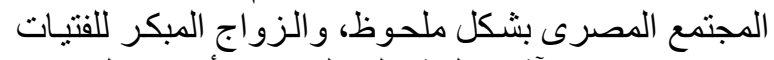

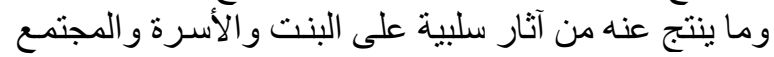
( الهادى ودحروج، 2017)

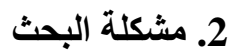

الفتيـات هـن أمهات المستقبل، فلـو أن الأم أرضـت

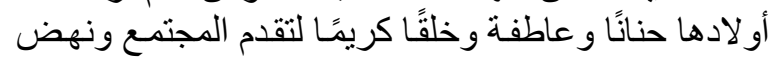

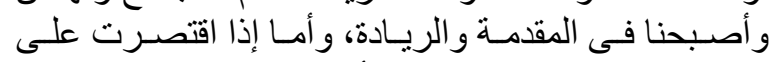

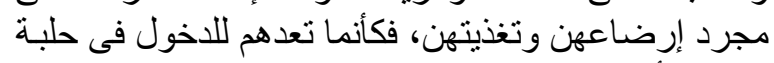

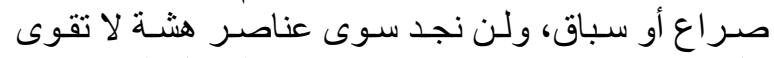

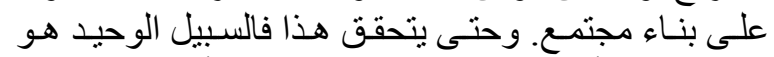

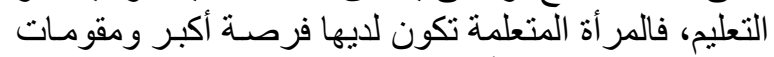

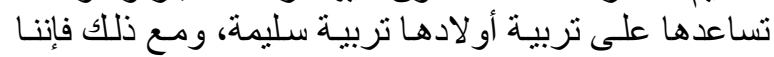




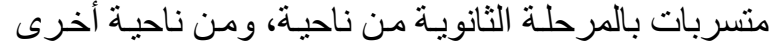

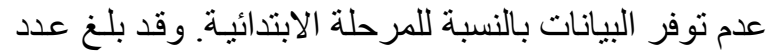

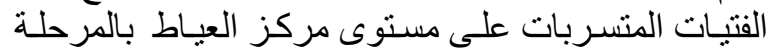

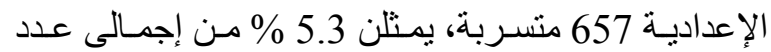

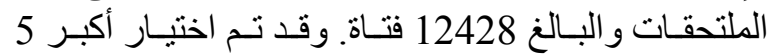

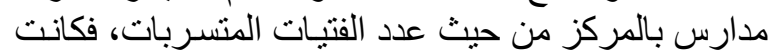

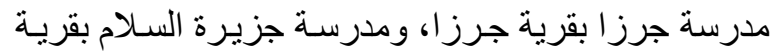

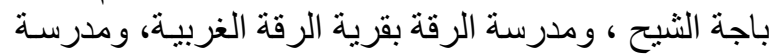

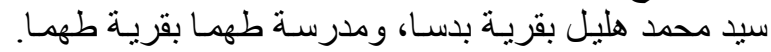

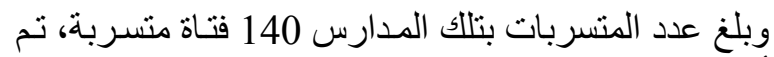

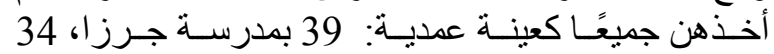

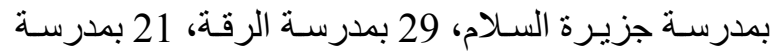

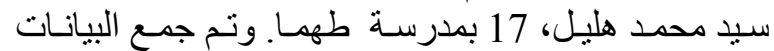

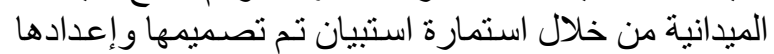

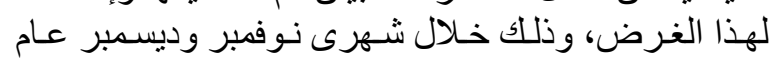

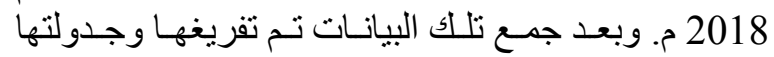

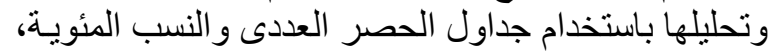

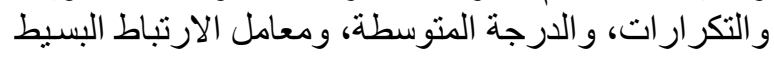

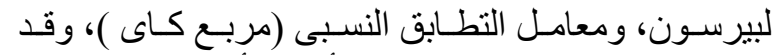
اشتملت استمارة الاستبيان على أربعـة أقسـام على النحو

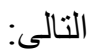

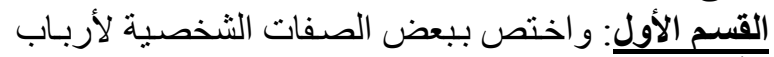

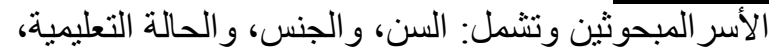

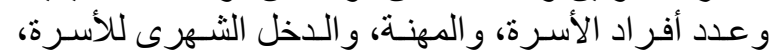

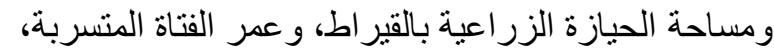
ومو عد ترك الفتاة للمدرسة.

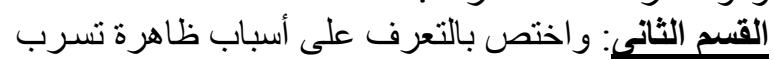

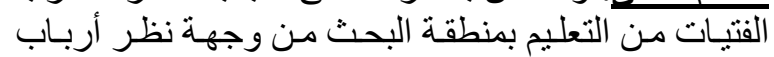

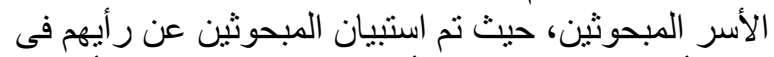

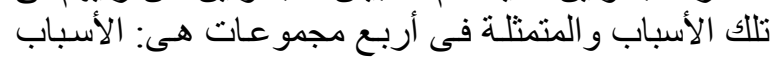

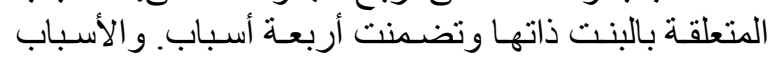

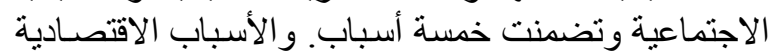

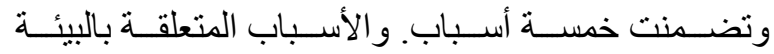

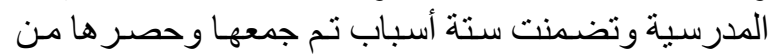

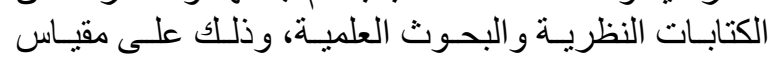

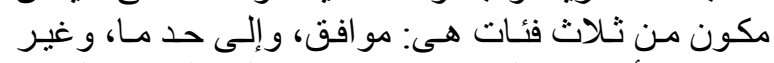

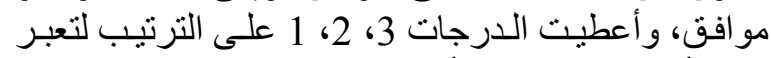

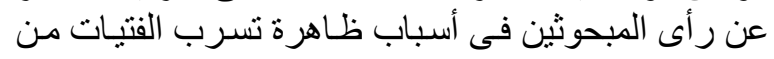

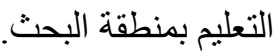

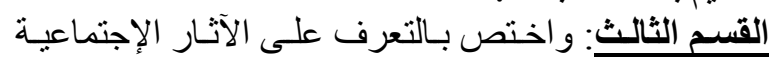

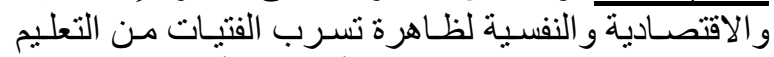

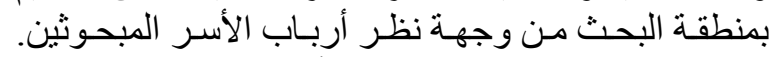
حيث تم استبيان المبحوثين عن رأيهم في الآثار المترتبـة المثية

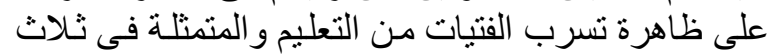

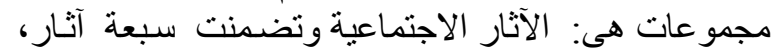

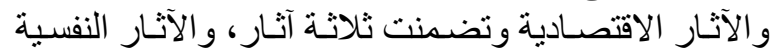

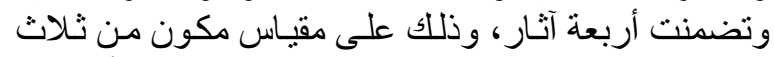

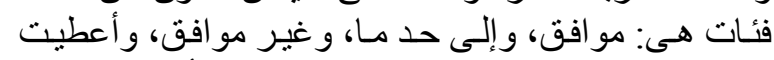
الدرجات 3، 2، 1 على الترتيب لتعبر عن رغير مأى المبحوثين
درجـة أهميـة الآثار الاجتماعيـة المترتبـة على ظـاهرة تسرب الفتيات من التعليم. تصني 9-تحديد معنوية العلاقة بين الصفات التالية لأرباب الأسر

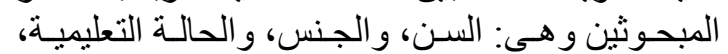

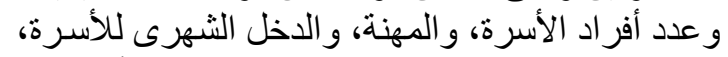

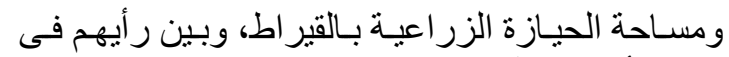

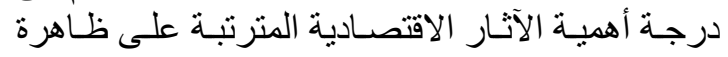
تسرب الفتيات من التعليم.

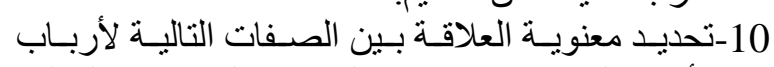

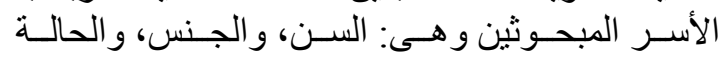

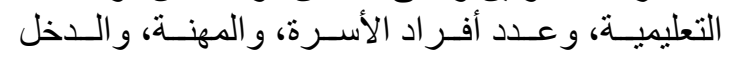

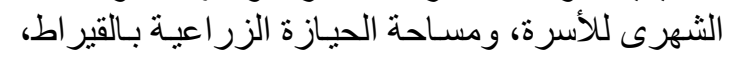

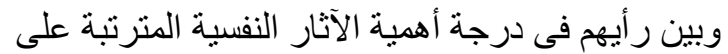

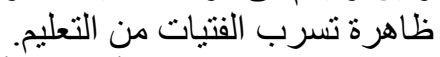

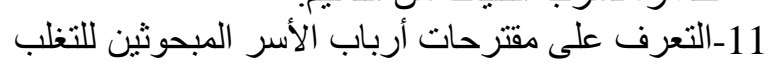
على ظاهرة تسرب الفتيات من التعليم.

\section{3 الفروض البحثية}

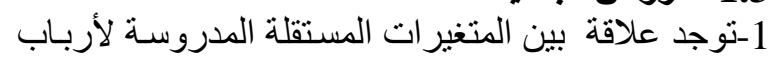

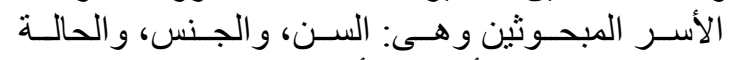

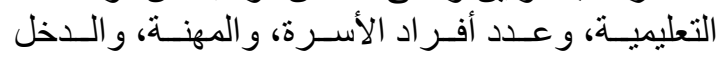

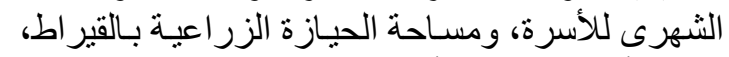

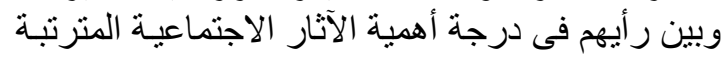
على ظاهرة تسرب الفتيات دن من التعليم.

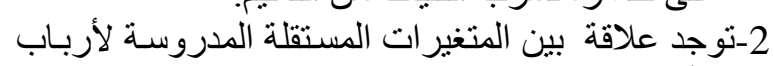

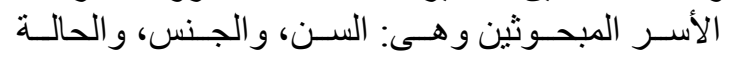

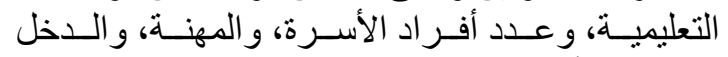

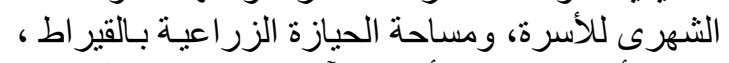

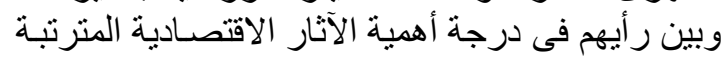

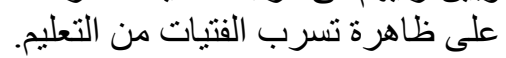

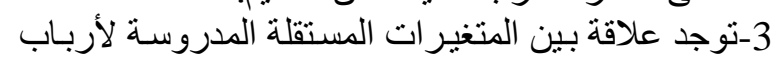

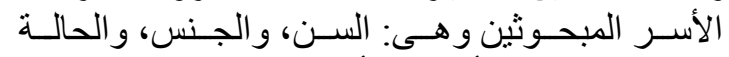

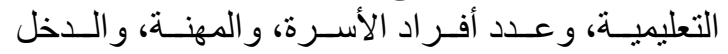

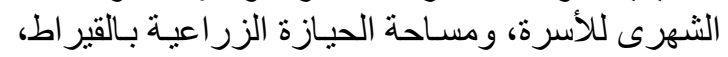

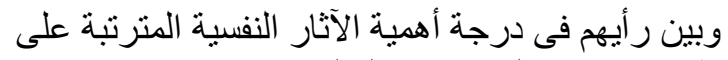
ظاهرة تسرب الفتيات من التعليم.

2.3 الفروض الإحصائية لاختبار صحة الفروض الإحصة النظرية تم صياغة الفروض

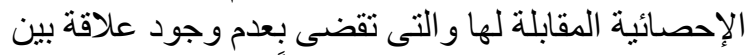
المتغير ات المدروسة والمفابلة المذكورة سابقًا.

\section{4. - الطريقة البحثية}

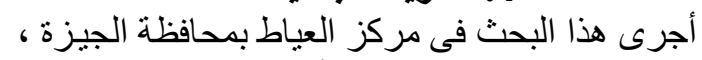

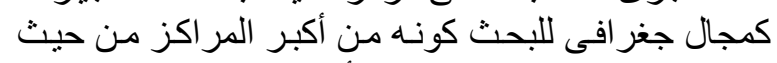

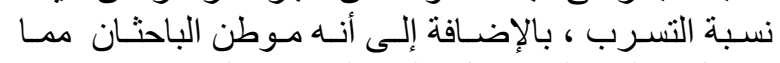

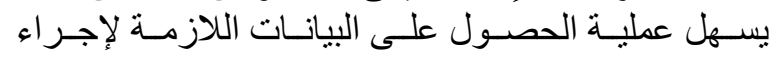

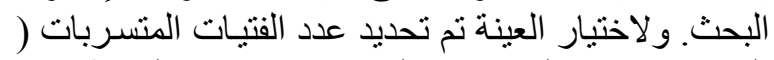

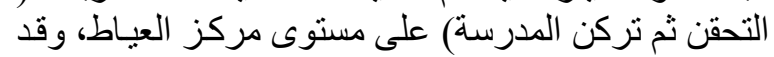
نم الاقتصار فقط على المرحلة الإعدادية، لعدم وجود فتئيات العيات 
الثانية) بدرجة متوسطة قدر ها 1.1 درجة ، ثم شعور البنت بالنقص والاضطهاد، و علاقاتها غير الجيدة داخدة داخل المدرسة

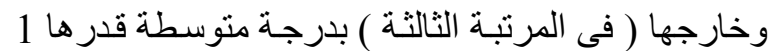

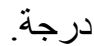

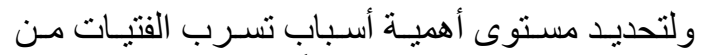

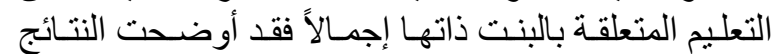

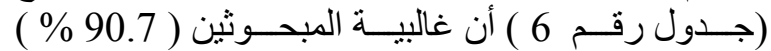

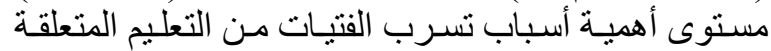

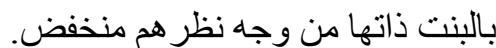

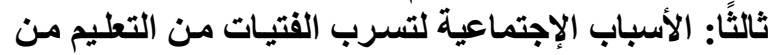
وجهة نظر أرباب الأسر المبحوثين الإبين

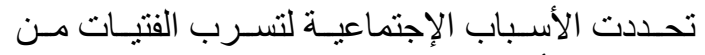

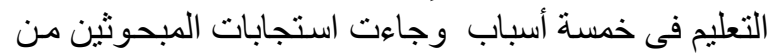

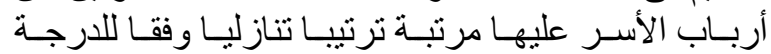

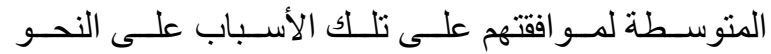

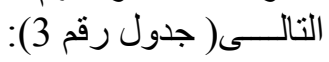

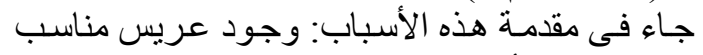

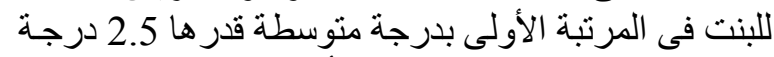

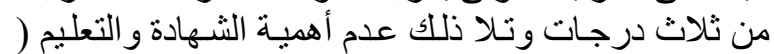

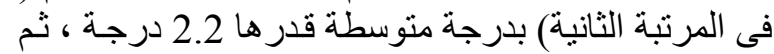

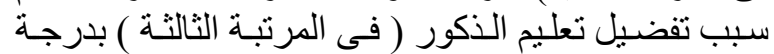

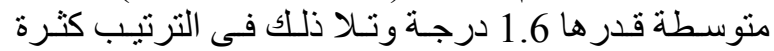

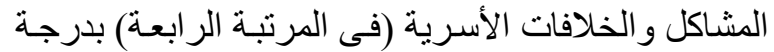

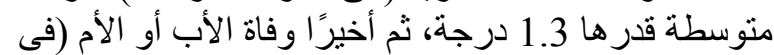

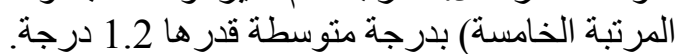
ولتحديد مسنوى أهمية الأسباب الاجتماعية إجمالاً فقد

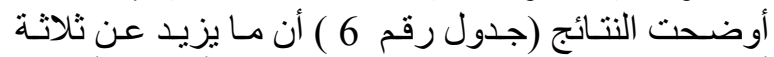
أربـاع المبحوثين (77.1 \% \%) كان مستوى أهميـة الأسباب

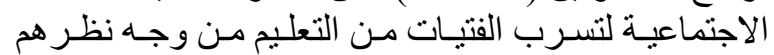

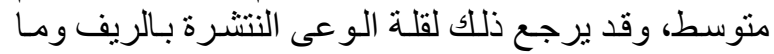

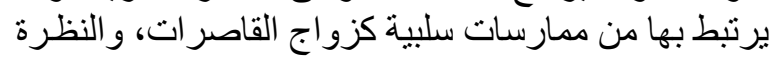

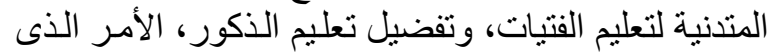

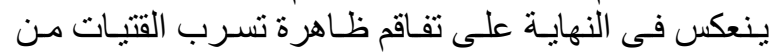

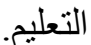

رابعا: الأسباب الاقتصادية لتسرب الفتيات من التعليم من وجهة نظر أرباب الأسر المبحوثين التين

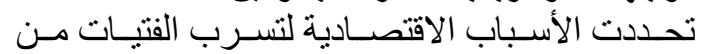

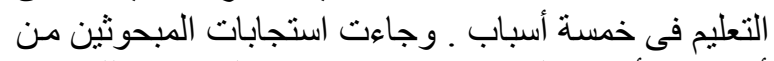

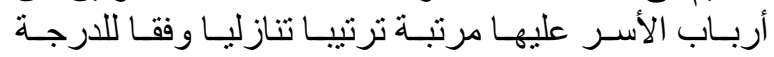

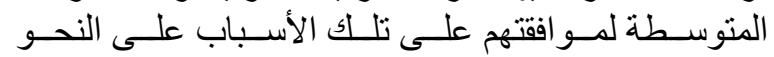

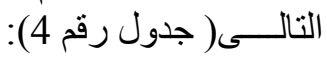
جاء فى مقدمة هذه الأسباب: كلاً من عدم القدرة على لَى

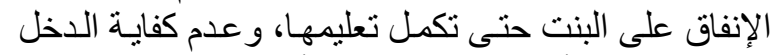

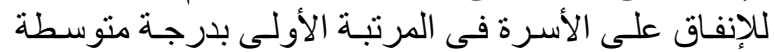

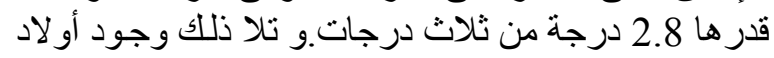

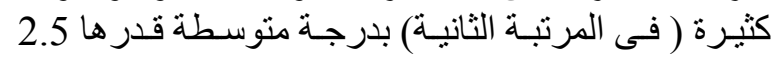

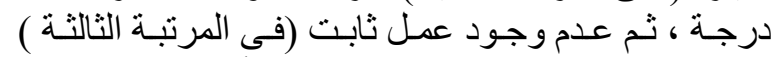

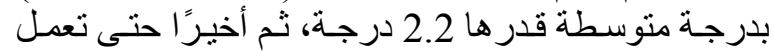

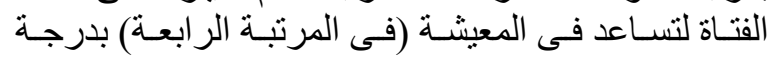
متوسطة قدرها 2.1 درجة.
فى الآثار المترتبة على ظـاهرة تسرب الفتيات من التعليم

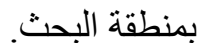

القسم الرابع: واختص بمقترحات أرباب الأسر المبحوثين

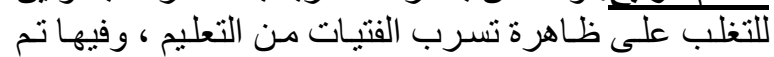

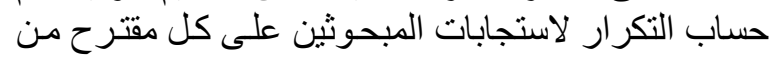

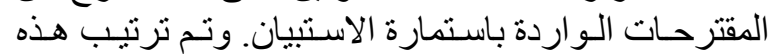

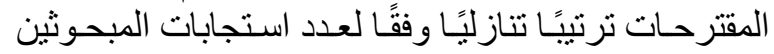
على كل مقترح.

\section{5. النتائج ومناقشتها} أولا: وصف عينة البحث

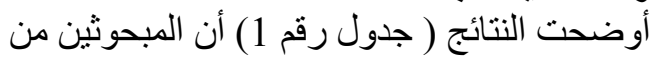

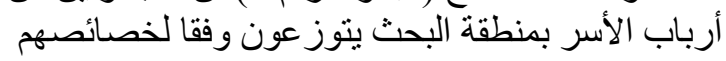
المدروسة على النحو النالى:

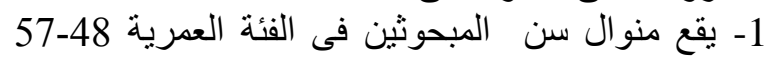
سنة وبلغت نسبتهم (45,7 \% \%)

2- الغالبية العظمى منهم (93,63\% (453\%) ذكور.

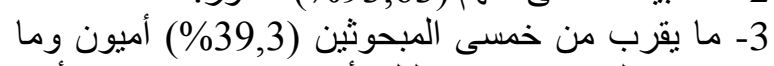

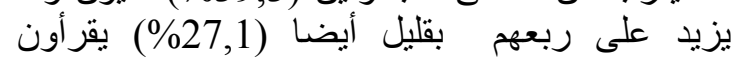

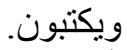

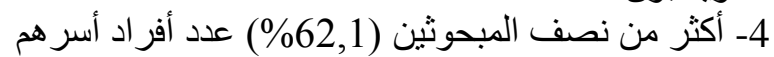

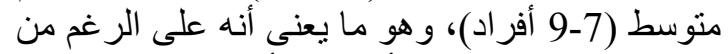

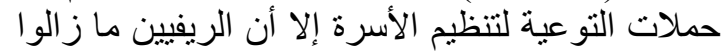

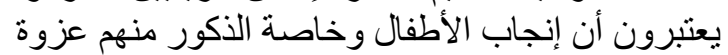
وقوة لهم داخل مجتمعهم المحلى.

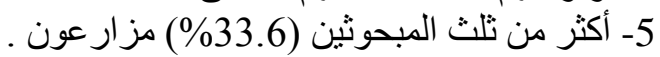

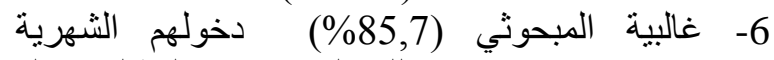

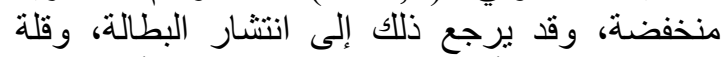

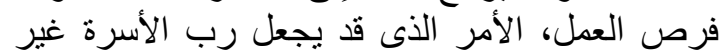

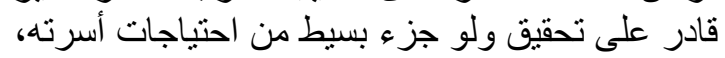
و الإنفاق على تعليم أو لاده.

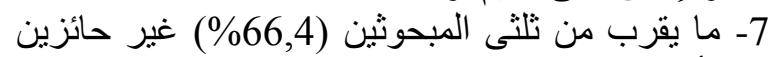

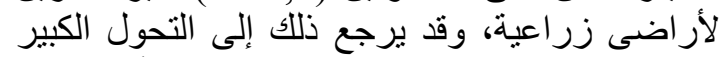

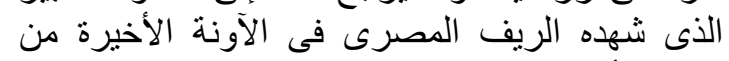
تبوير للأر اضى الزئ الزر اعية وبيعها والبناء عليها.

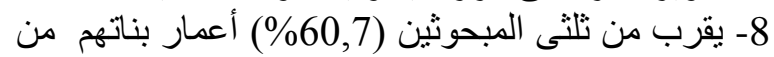

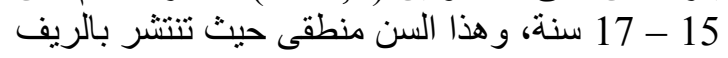

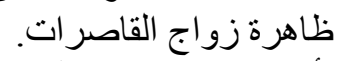
9- أكثر من نصف زواج الفبحوثين (55\%) بناتهم تركن

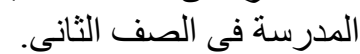

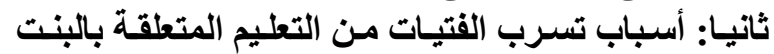
ذاتها من وجهة نظر أرباب الأسر المبحوثين المئن بالين

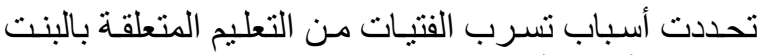

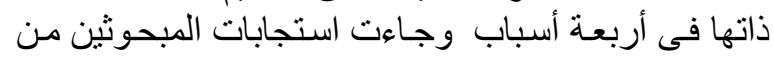

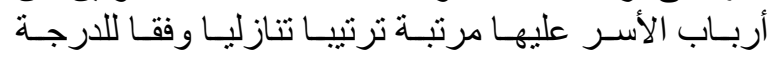

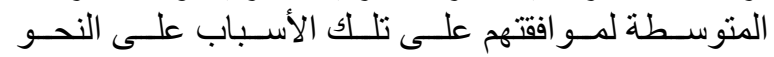

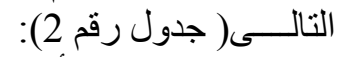

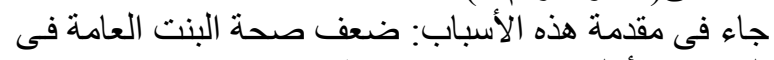

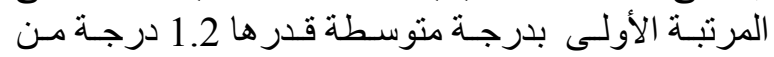

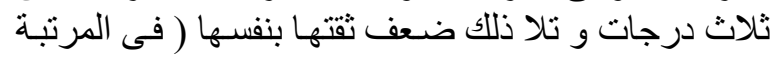




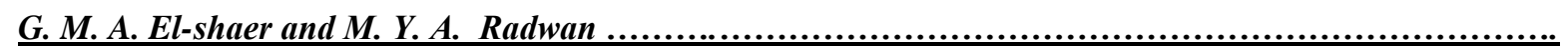

جدول رقم (1): توزيع أرباب أسر المبحوثين وفقًا لخصائصهم المدروسة.

\begin{tabular}{|c|c|c|c|c|c|}
\hline$\%$ & عدد & الخصائص & $\%$ & عدد & الخصائص \\
\hline & & 5- المهنة:ة & & & 1- السن: \\
\hline 33.6 & 47 & مزارع & 39.3 & 55 & 38- 47 سنة \\
\hline 26.4 & 37 & عامل & 45.7 & 64 & 48- 57 سنة \\
\hline 6.4 & 9 & موظف & 15 & 21 & 58- 65 سنة \\
\hline 6.3 & 9 & معاش & & & \\
\hline 27.1 & 38 & أعمال حرة & & & \\
\hline 100 & 140 & المجموع & 100 & 140 & المجموع \\
\hline & & 6- الاخل: & & & 2- الجنس: \\
\hline 85.7 & 120 & منخفض( 1200-2000) & 93.6 & 131 & ذكر \\
\hline 10.7 & 15 & متوسط( 2100-2900) & 6.4 & 9 & أنثى \\
\hline 3.6 & 5 & عالى( 3000-3500) & & & \\
\hline 100 & 140 & المجموع & 100 & 140 & المجموع \\
\hline & & 7- الحيازة الزراعية: & & & 3- الحالة التعليمية: \\
\hline 66.4 & 93 & غير حائز & 39.3 & 55 & \\
\hline 0.7 & 1 & منخفضة (1-9) قير اط & 27.1 & 38 & يقر أ و يكتب \\
\hline 23.6 & 33 & متوسطة (10-18) قير اط & 12.1 & 17 & إبتدائبة \\
\hline 9.3 & 13 & عالية (19- 24) قير اط & 8.6 & 12 & إعدادية \\
\hline & & & 12.1 & 17 & مؤ هل متوسط \\
\hline & & & 0.7 & 1 & مؤهل عالى \\
\hline 100 & 140 & المجموع & 100 & 140 & المجموع \\
\hline & & 8 & & & 4- عدد أفر اد الأسرة: \\
\hline 60.7 & 85 & 15 - 17 سنة & 33.6 & 47 & أسرة صغيرة 4-6 أفر اد \\
\hline 34.3 & 48 & 18 - 19 سنة & 62.1 & 87 & أسرة منوسطة 7-9 أفر اد \\
\hline 5 & 7 & $21-20$ & 4.3 & 6 & أسرة كبيرة 10-11 فرد \\
\hline \multirow[t]{7}{*}{100} & 140 & المجموع & 100 & 140 & المجموع \\
\hline & & & & & 9 - السنة الدراسية التى تركت \\
\hline & & & & & فيها البنت المدرسة:ة \\
\hline & & & 25 & 35 & الصف الأول \\
\hline & & & 39.3 & 55 & الصف الثانى \\
\hline & & & 35.7 & 50 & الصف الثالث \\
\hline & & & 100 & 140 & المجموع \\
\hline
\end{tabular}

جدول رقم (2): توزيع أرباب أسر المبحوثين وفقًا لرأيهم فى أسباب تسرب الفتيات من التعليم المتعلقة بالبنت ذاتها.

\begin{tabular}{|c|c|c|c|c|c|c|c|c|c|c|c|}
\hline \multirow{2}{*}{ الترتيب } & \multirow{2}{*}{ المرجح المتوسـط } & \multicolumn{2}{|c|}{ 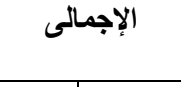 } & \multicolumn{2}{|c|}{ موافير } & \multicolumn{2}{|c|}{ إلى حـ } & \multicolumn{2}{|c|}{ 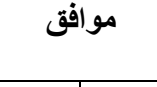 } & \multirow[b]{2}{*}{ الأسباب المتعلقة بالبنت } & \multirow[b]{2}{*}{ r } \\
\hline & & $\%$ & عدد & $\%$ & عدد & $\%$ & عدد & $\%$ & عدد & & \\
\hline 1 & 1.2 & 100 & 140 & 89.3 & 125 & 5 & 7 & 5.7 & 8 & ضعف صحة البنت العامة & 1 \\
\hline 2 & 1.1 & 100 & 140 & 92.1 & 129 & 7.9 & 11 & 0 & 0 & ضعف ثقتها بنفسها & 2 \\
\hline 3 & 1 & 100 & 140 & 95.7 & 134 & 4.3 & 6 & 0 & 0 & شعور ها بالنقص والاضطهاد & 3 \\
\hline 3 & 1 & 100 & 140 & 97.9 & 137 & 2.1 & 3 & 0 & 0 & علاقاتها متدنية داخل المدرسة وخارجها & 4 \\
\hline
\end{tabular}

\begin{tabular}{|c|c|c|c|c|c|c|c|c|c|c|c|}
\hline \multirow{2}{*}{ الترتيب } & \multirow{2}{*}{ المرجح المتوســ } & \multicolumn{2}{|c|}{ الإجمالى } & \multicolumn{2}{|c|}{ موافير } & \multicolumn{2}{|c|}{ إلى حد } & \multicolumn{2}{|c|}{ موافق } & \multirow[t]{2}{*}{ إنى المبحوثين } & \multirow[b]{2}{*}{ r } \\
\hline & & $\%$ & عدد & $\%$ & عدد & $\%$ & عدد & $\%$ & عدد & & \\
\hline 2 & 2.2 & 100 & 140 & 17.9 & 25 & 41.4 & 58 & 40.7 & 57 & عدم أهمية الشهادة والتعليم & 1 \\
\hline 1 & 2.5 & 100 & 140 & 23.6 & 33 & 0 & 0 & 76.4 & 107 & وجود عريس للبنت & 2 \\
\hline 4 & 1.3 & 100 & 140 & 79.3 & 111 & 12.9 & 18 & 7.9 & 11 & الخلافات الأسرية & 3 \\
\hline 3 & 1.6 & 100 & 140 & 54.3 & 76 & 30 & 42 & 15.7 & 22 & من أجل تعليم الأكور & 4 \\
\hline 5 & 1.2 & 100 & 140 & 90 & 126 & 2.1 & 3 & 7.9 & 11 & وفاة الأب أو الأم & 5 \\
\hline
\end{tabular}




\begin{tabular}{|c|c|c|c|c|c|c|c|c|c|c|c|}
\hline & & & & من & الفتي & 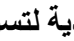 & الاقتص & 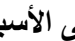 & كائم & قم (4) :توزيع أرباب أسر المبحوثين & جدول \\
\hline \multirow{2}{*}{ الترتيب } & \multirow{2}{*}{ المرجح } & \multicolumn{2}{|c|}{ الإجمالى } & \multicolumn{2}{|c|}{ موافِق } & \multicolumn{2}{|c|}{ إلى حـا } & \multicolumn{2}{|c|}{ موافق } & \multirow[t]{2}{*}{ إنى المبحوثين } & \multirow[b]{2}{*}{ s } \\
\hline & & $\%$ & عدد & $\%$ & عدد & $\%$ & عدد & $\%$ & عدد & & \\
\hline 1 & 28 & 100 & 140 & 14 & 2 & 193 & 27 & 7 & 111 & 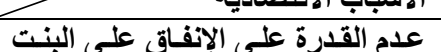 & 1 \\
\hline & & & & & & & & & & 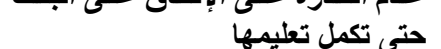 & \\
\hline 1 مكرر & 2.8 & 100 & 140 & 1.4 & 2 & 18.6 & 26 & 80 & 112 & عدم كفاية الاخل للإنفاتق على الأسرة & 2 \\
\hline 3 & 2.2 & 100 & 140 & 25.7 & 36 & 32.1 & 45 & 42.1 & 59 & عل ع وجود عمل ثابت & 3 \\
\hline 4 & 2.1 & 100 & 140 & 27.9 & 39 & 34.3 & 48 & 37.9 & 53 & حتى تعمل لتساعد في المعيثة & 4 \\
\hline 2 & 2.5 & 100 & 140 & 10 & 14 & 32.1 & 45 & 57.9 & 81 & 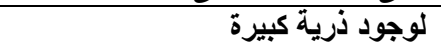 & 5 \\
\hline
\end{tabular}

جاء فى مقدمة هذه الآثار كلاً من انتشـار الأميـة وقلـة

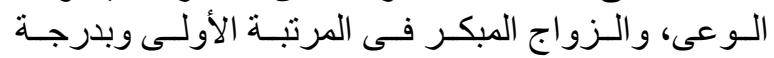

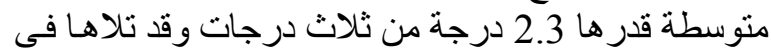

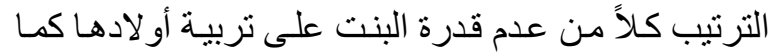

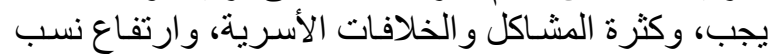

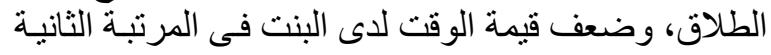

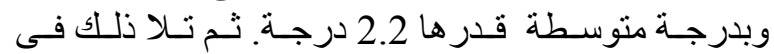

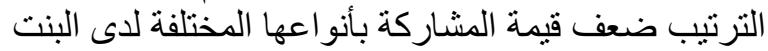

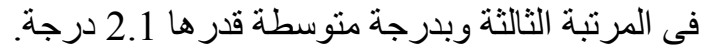

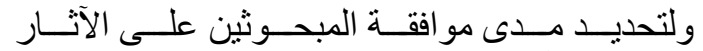

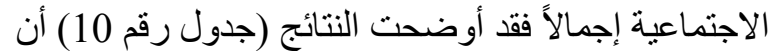

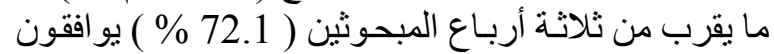

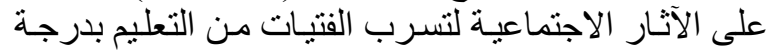

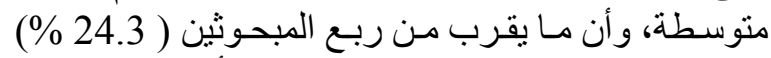

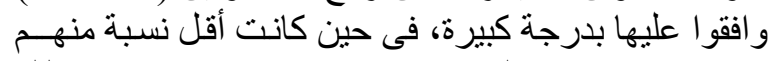

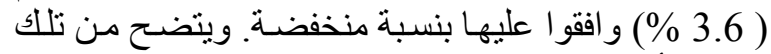

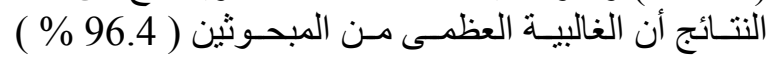

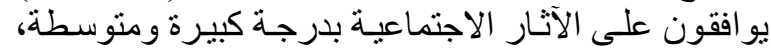

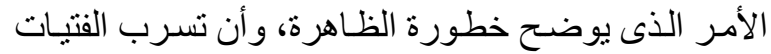

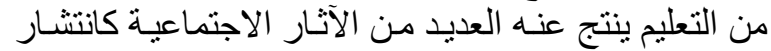

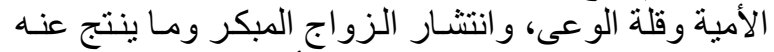

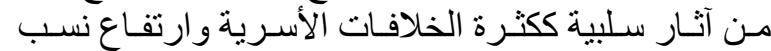

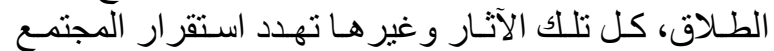

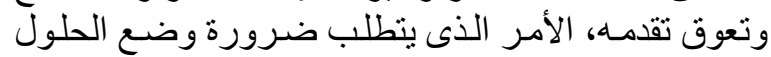

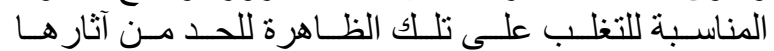

الاجتماعية.

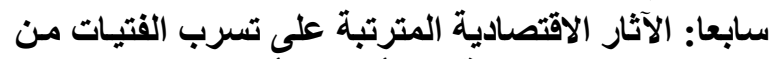

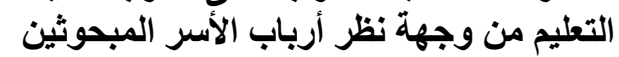

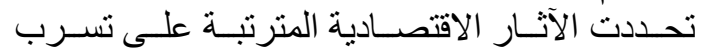

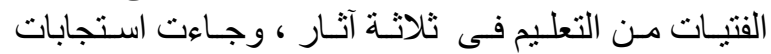

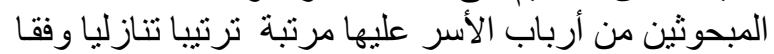

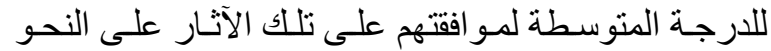

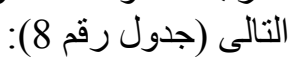

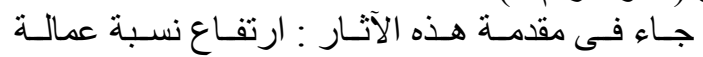

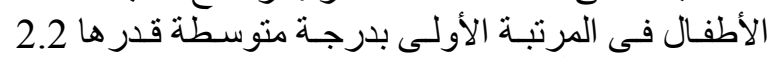

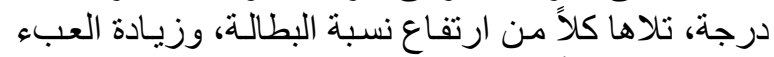

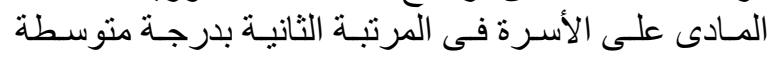
قدرها 2.1 درجة من ثلاث درجات.
ولتحديد مستوى أهمية الأسباب الاقتصادية إجمالاً فقد

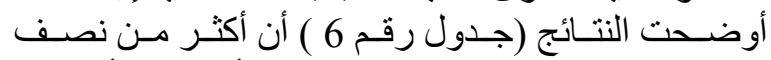

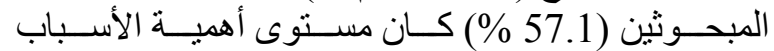

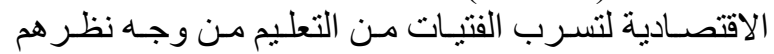

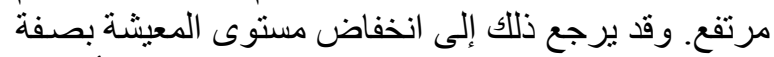

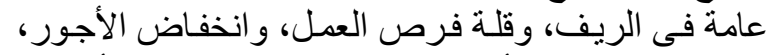

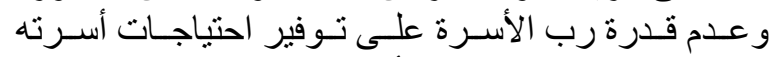

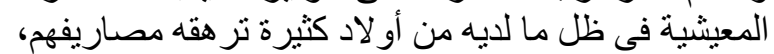

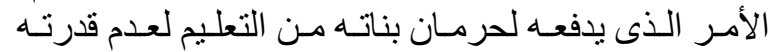

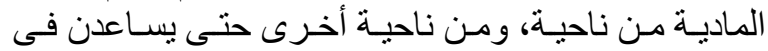

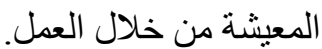

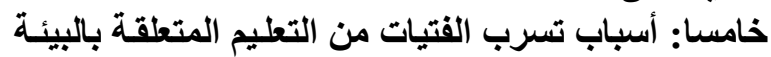

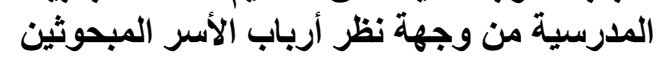

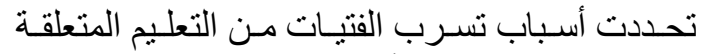

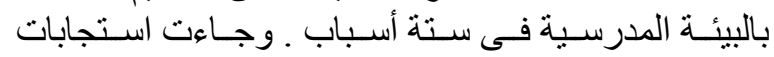

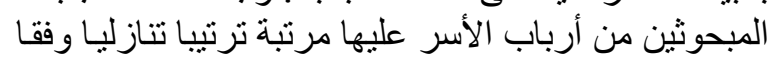
للارجة المنوسطة لمو افقتهم على تللك الأسباب على اللى النحو

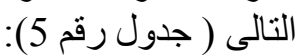

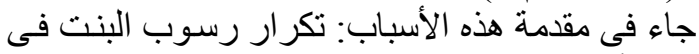

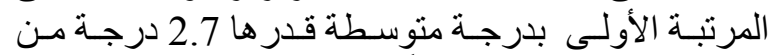

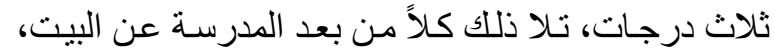

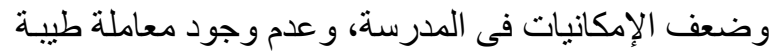

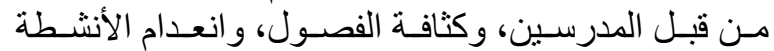

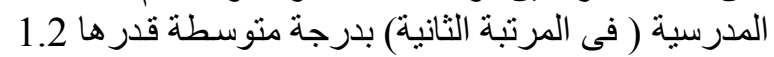

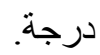

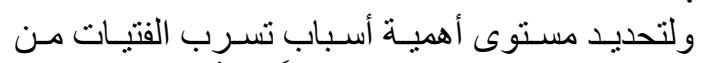

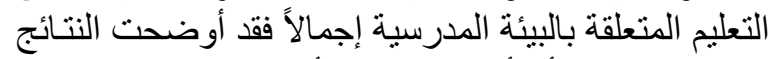

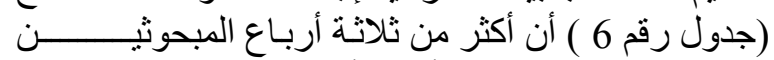

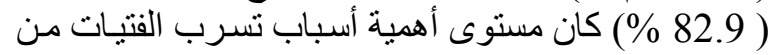

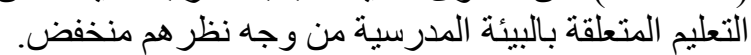

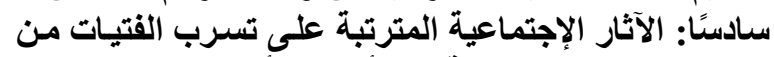

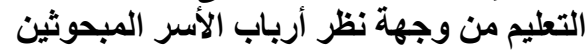

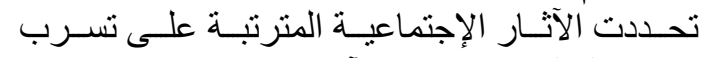

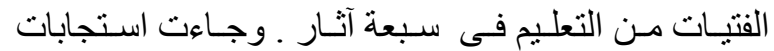

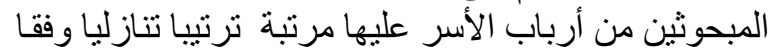

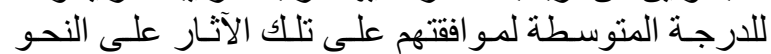

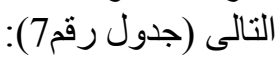


جدول رقم (5) :توزيع أرباب أسر المبحوثين وفقًا لرأيهم فى أسباب تسرب الفتيات من التعليم المتعلقة بالبيئة المدرسية.

\begin{tabular}{|c|c|c|c|c|c|c|c|c|c|c|c|}
\hline \multirow{2}{*}{ الترتيب } & \multirow{2}{*}{ المرجح } & \multicolumn{2}{|c|}{ الإجمالى } & \multicolumn{2}{|c|}{ مو غير } & \multicolumn{2}{|c|}{ إلى حـ } & \multicolumn{2}{|c|}{ موافق } & \multirow[t]{2}{*}{ ] رأى المبحوثين } & \multirow[b]{2}{*}{ r } \\
\hline & & $\%$ & عدد & $\%$ & عدد & $\%$ & عدد & $\%$ & عدد & & \\
\hline 1 & 2.7 & 100 & 140 & 1.4 & 2 & 24.3 & 34 & 74.3 & 104 & تكرار رسوب البنت & 1 \\
\hline 2 & 1.2 & 100 & 140 & 83.6 & 117 & 11.4 & 16 & 5 & 7 & بعد المدرسة عن البيت & 2 \\
\hline 2 & 1.2 & 100 & 140 & 83.6 & 117 & 13.6 & 19 & 2.9 & 4 & ضعف الإمكانيات في المدرسة & 3 \\
\hline 2 & 1.2 & 100 & 140 & 83.6 & 117 & 13.6 & 19 & 2.9 & 4 & المدرسين وجود معاملـة طيبة من قبل & 4 \\
\hline 2 & 1.2 & 100 & 140 & 83.6 & 117 & 13.6 & 19 & 2.9 & 4 & كثافة الفصول & 5 \\
\hline 2 & 1.2 & 100 & 140 & 84.3 & 118 & 12.9 & 18 & 2.9 & 4 & انعدام الأنشطة المدرسية & 6 \\
\hline
\end{tabular}

جلول رقم (6): توزيع أرباب أسر المبحوثين وفقًا لمستوى أهمية أسباب تسرب الفتيات من التعليم المتعلقة بالبنت ذاتها، والأسباب

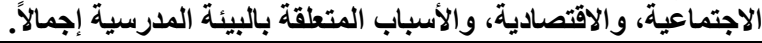

\begin{tabular}{|c|c|c|c|c|c|c|c|c|c|}
\hline \multicolumn{2}{|c|}{ بالبيئة المدرسبية متعلقة } & \multicolumn{2}{|c|}{ الاقتصادية } & \multicolumn{2}{|c|}{ الأسباب الاجتماعية } & \multicolumn{2}{|c|}{ أسباب متعلقة } & \multirow[t]{2}{*}{ الأسباب } & \multirow[b]{2}{*}{ r } \\
\hline$\%$ & عدد & $\%$ & عدد & $\%$ & عدد & $\%$ & عدد & & \\
\hline 82.9 & 116 & 7.9 & 11 & 12.9 & 18 & 90.7 & 127 & منخفض & 1 \\
\hline 13.6 & 19 & 35 & 49 & 77.1 & 108 & 5 & 7 & متوسط & 2 \\
\hline 3.6 & 5 & 57.1 & 80 & 10 & 14 & 4.3 & 6 & مرتفع & 3 \\
\hline
\end{tabular}

جلول رقم (7): توزيع أرباب أسر المبحوثين وفقًا لرأيهم فى الآثار الاجتماعية المترتبة على تسرب الفتيات من التعليح.

\begin{tabular}{|c|c|c|c|c|c|c|c|c|c|c|c|}
\hline \multirow{2}{*}{ الترتيب } & \multirow{2}{*}{ المرجت المتط } & \multicolumn{2}{|c|}{ الإجمالى } & \multicolumn{2}{|c|}{ موافيز } & \multicolumn{2}{|c|}{ إلى حـ } & \multicolumn{2}{|c|}{ موافق } & & \multirow{2}{*}{ e } \\
\hline & & $\%$ & عدد & $\%$ & عدد & $\%$ & عدد & $\%$ & عدد & & \\
\hline 1 & 2.3 & 100 & 140 & 3.6 & 5 & 65.7 & 92 & 30.7 & 43 & انتشار الأمية وقلة الوعى & 1 \\
\hline 1 ا 1 مكرر & 2.3 & 100 & 140 & 0.7 & 1 & 66.4 & 93 & 32.9 & 46 & الزواج المبكر & 2 \\
\hline 2 & 2.2 & 100 & 140 & 3.6 & 5 & 72.1 & 101 & 24.3 & 34 & 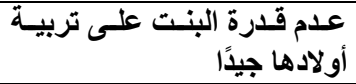 & 3 \\
\hline 2 مكرر & 2.2 & 100 & 140 & 3.6 & 5 & 72.1 & 101 & 24.3 & 34 & وعثرة البنت & 4 \\
\hline 2 مكرر & 2.2 & 100 & 140 & 2.1 & 3 & 74.3 & 104 & 23.6 & 33 & ارتفاع نسب الطلاق & 5 \\
\hline 2 & 2.2 & 100 & 140 & 3.6 & 5 & 72.9 & 102 & 23.6 & 33 & ضعف قيمة الوقت لاى البنت & 6 \\
\hline 3 & 2.1 & 100 & 140 & 3.6 & 5 & 73.6 & 103 & 22.9 & 32 & المختلفة قيمة المشى البنتاركة بأنواعها & 7 \\
\hline
\end{tabular}

جدول رقم (8): توزيع أرباب أسر المبحوثين وفقًا لرأيهم في الآثار الاقتصادية المترتبة على تسرب الفتيات من التعليم.

\begin{tabular}{|c|c|c|c|c|c|c|c|c|c|c|c|}
\hline \multirow{2}{*}{ الترتيب } & \multirow{2}{*}{ المرجح } & \multicolumn{2}{|c|}{ الإجمالى } & \multicolumn{2}{|c|}{ غو غيز } & \multicolumn{2}{|c|}{ إلى حد } & \multicolumn{2}{|c|}{ موافق } & \multirow[t]{2}{*}{ ا رأى المبحوثين } & \\
\hline & & $\%$ & عدد & $\%$ & عدد & $\%$ & عدد & $\%$ & عدد & & \\
\hline 2 & 2.1 & 100 & 140 & 5 & 7 & 80.7 & 113 & 14.3 & 20 & ارتفاع نسبة البطالة & 1 \\
\hline 1 & 2.2 & 100 & 140 & 1.4 & 2 & 80.7 & 113 & 17.9 & 25 & ارتفاع نسبة عمالة الأطفال & 2 \\
\hline 2 مكرر & 2.1 & 100 & 140 & 4.3 & 6 & 81.4 & 114 & 14.3 & 20 & زلأسيسادة العسبء المــادى علـى & 3 \\
\hline
\end{tabular}


العظمى مـن المبحوثين (96.4 \%) يو افقون على الآثار

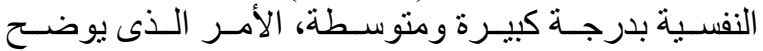

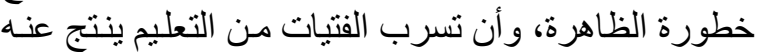

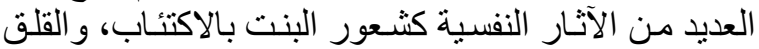

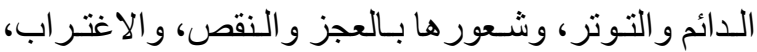

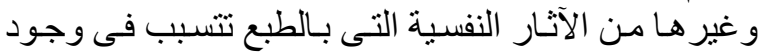

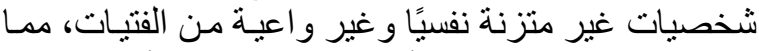

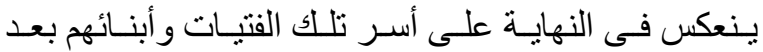

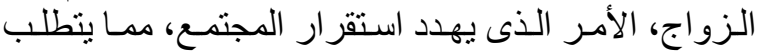

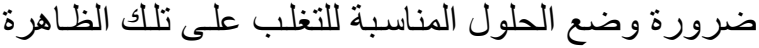
للحد من آثار ها النفسية. تاسعًا: العلاقة بين بعض الفئة المتغيرات المستقلة المدروسـة

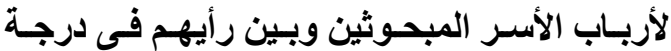

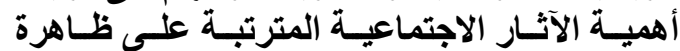

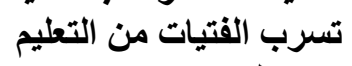
ينص الفرض الإحصـائى الأول على أنسه : لا توجد

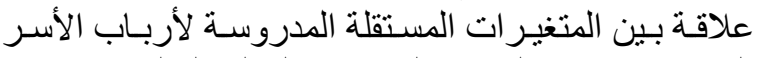

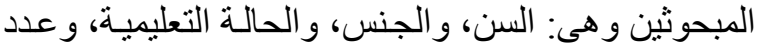

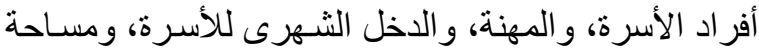

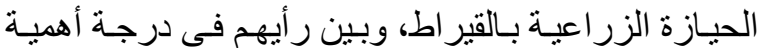

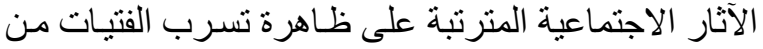

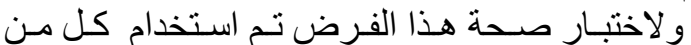

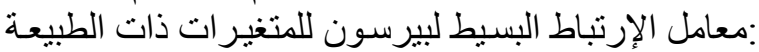

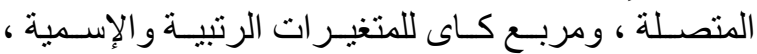

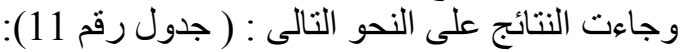

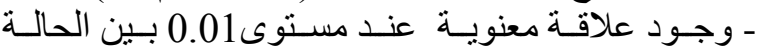

ولتحديد مدى مو افقة المبحوثين على الآثار الاقتصادية

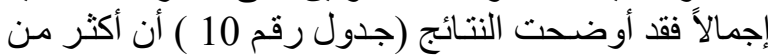

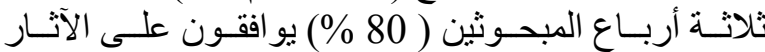

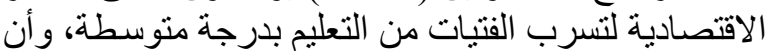

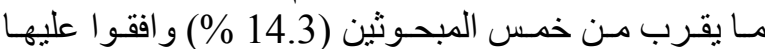

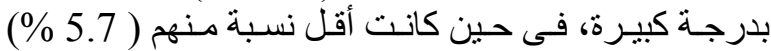

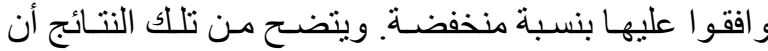

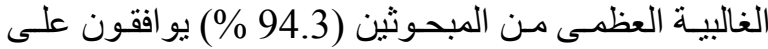

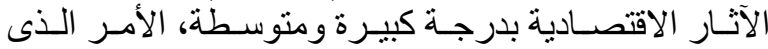

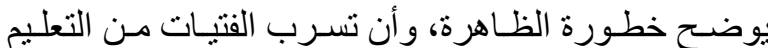

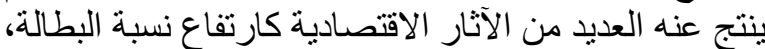

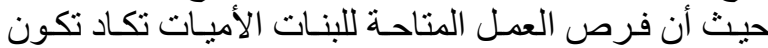

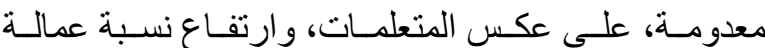

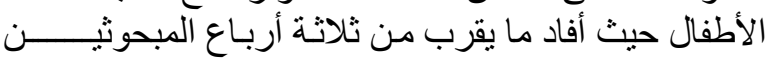

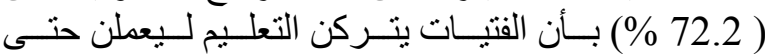

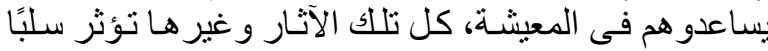

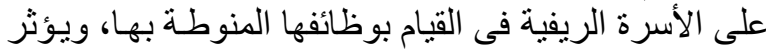

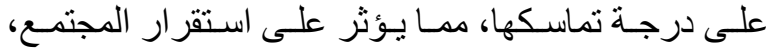

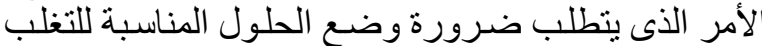

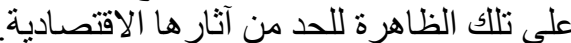

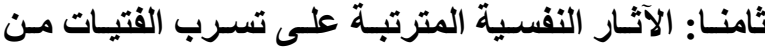
التعليم من وجهة نظر أرباب الأسر المبحوثين النئين

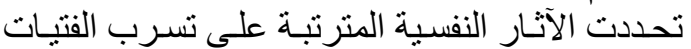

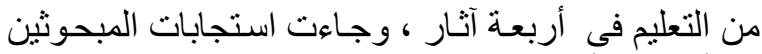

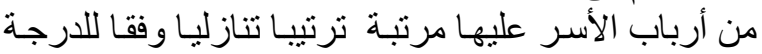

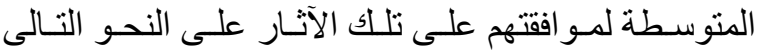

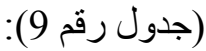

\begin{tabular}{|c|c|c|c|c|c|c|c|c|c|c|c|}
\hline \multirow{2}{*}{ الترتيب } & \multirow{2}{*}{ المرجح } & \multicolumn{2}{|c|}{ الإجمالى } & \multicolumn{2}{|c|}{ موافير } & \multicolumn{2}{|c|}{ إلى حا } & \multicolumn{2}{|c|}{ موافق } & \multirow[t]{2}{*}{ رأى المبحوثين } & \multirow[b]{2}{*}{ ? } \\
\hline & & $\%$ & عدد & $\%$ & عدد & $\%$ & عدد & $\%$ & عدد & & \\
\hline 1 & 2.2 & 100 & 140 & 3.6 & 5 & 75.7 & 106 & 20.7 & 29 & شعور البنت بالاكتئاب & $\mathbf{1}$ \\
\hline 1 مكرر & 2.2 & 100 & 140 & 3.6 & 5 & 75.7 & 106 & 20.7 & 29 & الثعور اللائم بالقلق والتوتر & 2 \\
\hline 1 مكرر 1 & 2.2 & 100 & 140 & 3.6 & 5 & 75.7 & 106 & 20.7 & 29 & الثُعور اللائم بالنقص والعجز & 3 \\
\hline 2 & 2.1 & 100 & 140 & 3.6 & 5 & 77.1 & 108 & 19.3 & 27 & الثعور بعدم الانتماء & 4 \\
\hline
\end{tabular}

التعليميـة للمبحوثين، وبين رأيهم في درجـة أهميـة الآثار

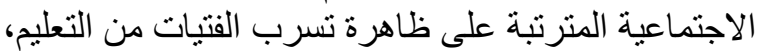

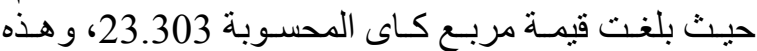

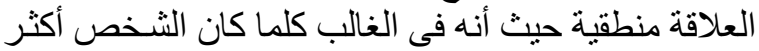

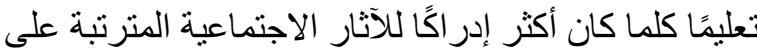
ظاهرة تسرب الفتيات من التعليج. ـ عدم وجود علاقة معنوية بين باقى المتغير التيرات المستقلة المدروسة للمبحوثين، وبين رأيهم في درجة المئة أهمية الآثار

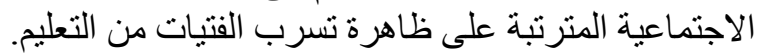

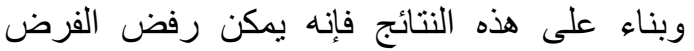

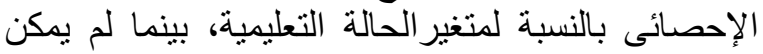

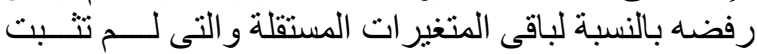

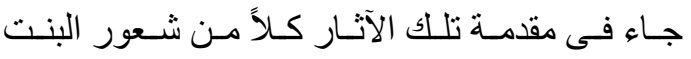

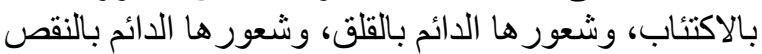

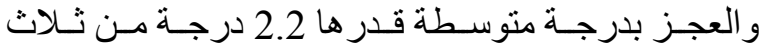

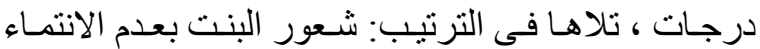
بدرجة منوسطة قدر ها 2.2 درجة.

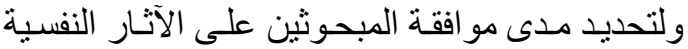

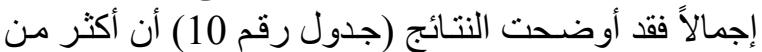

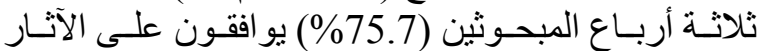

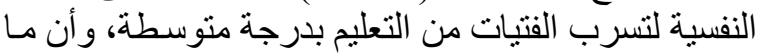

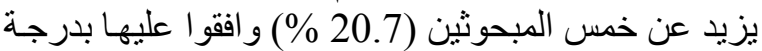

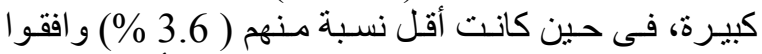
عليها بنسبة منخفضة، وينة ويتضح من تلانك النتائج أن الغالبيــــة 
تسبب فى زيادة الضغط و العبء المـادى على الأسرة، مهـا

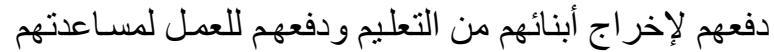

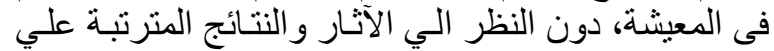

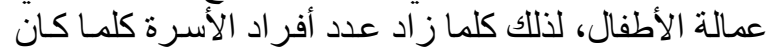

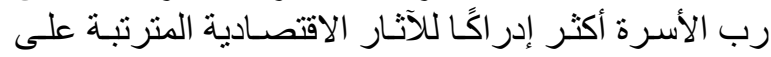

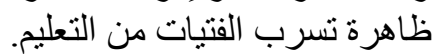

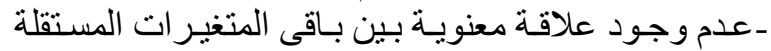

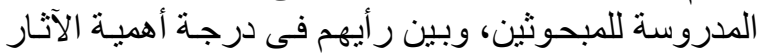

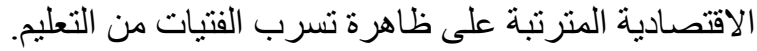

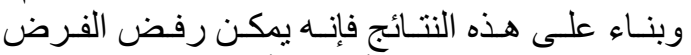

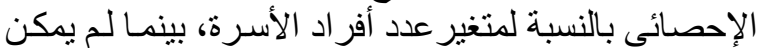

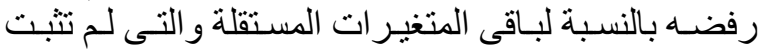

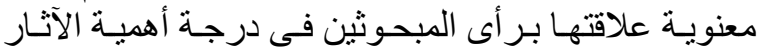

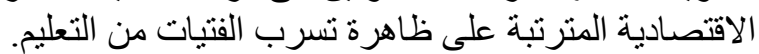

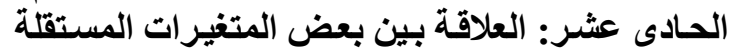
المدروسة لأرباب الأسر المبحوثين وبين الماتين

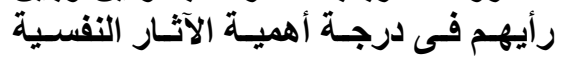

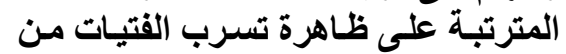

$$
\text { التعليم }
$$

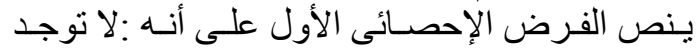

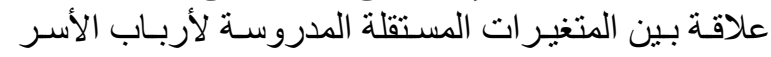

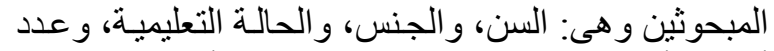

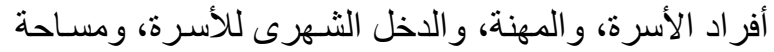

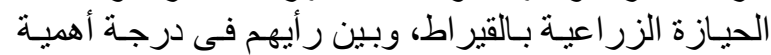

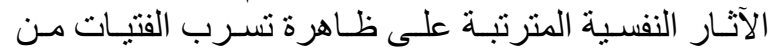

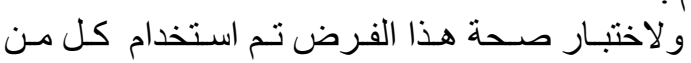

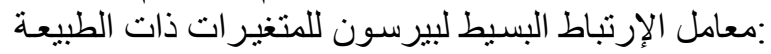

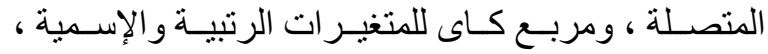

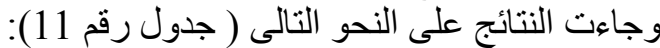

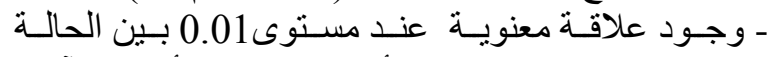

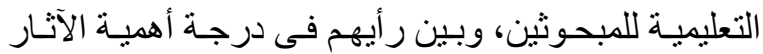

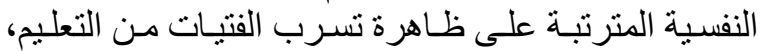

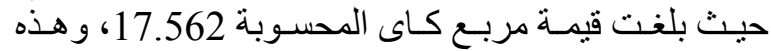
العلاقة منطقية حيث أنه فى الغالب كلما كان الثخدص أكثر

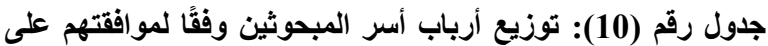

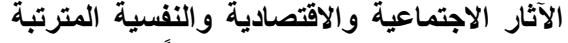

على تسرب الفتبات من التعليم إجمالاً.

\begin{tabular}{|c|c|c|c|c|c|c|c|}
\hline \multicolumn{2}{|c|}{ الآثار النفسية } & \multicolumn{2}{|c|}{ الاقتصادية } & \multicolumn{2}{|c|}{ الاجتماعية } & \multirow{2}{*}{ المستوباب } & \multirow[b]{2}{*}{ ? } \\
\hline$\%$ & عدد & $\%$ & عدد & $\%$ & عدد & & \\
\hline 3.6 & 5 & 5.7 & 0 & 3.6 & 5 & منففض & \\
\hline 75.7 & 106 & 80 & 112 & 72.1 & 101 & متوسط & 2 \\
\hline 20.7 & 29 & 14.3 & 20 & 24.3 & 34 & مرتف & \\
\hline
\end{tabular}

الاجنويـة علاقتهـا بـر أى المبحـوثين فـى درجـة أهميـة الآثـار

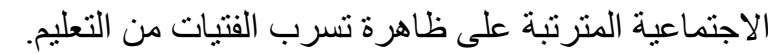

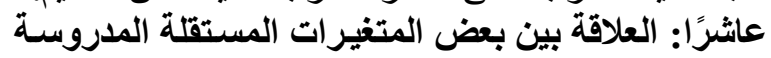

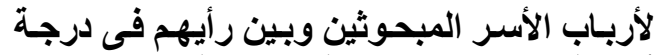

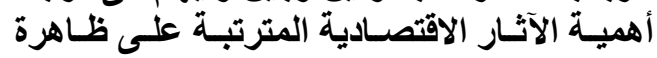

$$
\text { تسرب الفتيات من التعليم الآنيم }
$$

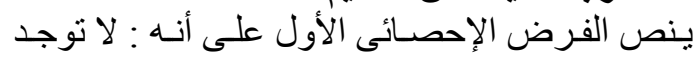

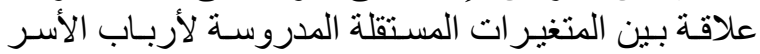

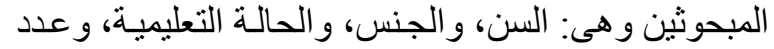

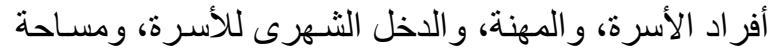

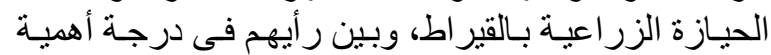

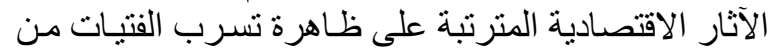

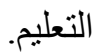
و لاختبار صحة هذا الفرض تم استخدام كل من :معامل

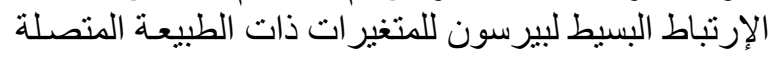

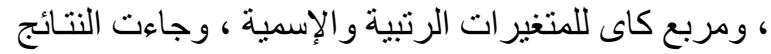

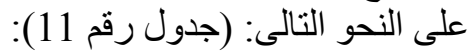

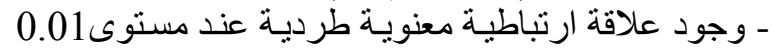

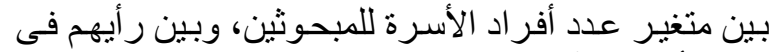

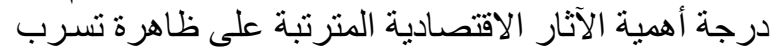

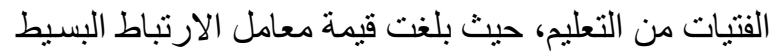
0.002. وقد يرجع ذلك إلـي أن زيـادة عدد أفر اد الأسرة

جدول رقم (11): قيم معامل الارتباط البسيط ومربع كاى للعلاقة بين المتغيرات المستقلة المدروسة لارباب الأسر المبحوثين وبين

\begin{tabular}{|c|c|c|c|}
\hline \multicolumn{3}{|c|}{ قيم معامل الارتباط البسيط } & \multirow{2}{*}{ المتغيرات المستقلة المدروسة } \\
\hline الآثار النفسية & الآثار الاقتصادية & الآثار الاجتماعية & \\
\hline $0.075-$ & 0.038 & 0.010 & السن \\
\hline $0.085-$ & $* * \mathbf{0 . 0 0 2}$ & $0.005-$ & عدد أفراد الأسرة \\
\hline 0.057 & $0.006-$ & 0.062 & الاخل الثهرى للأسرة \\
\hline $0.157-$ & $0.031-$ & $0.115-$ & مساحة الحيازة الزراعية \\
\hline \multicolumn{4}{|c|}{ قيم مربع كاي } \\
\hline 4.154 & 10.004 & 18.401 & الجنس \\
\hline$* * 17.562$ & 14.847 & $* * 23.303$ & الحالة التعليمية \\
\hline 21.151 & 26.647 & 39.626 & المهنة \\
\hline
\end{tabular}

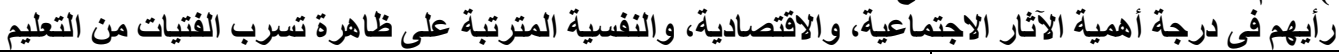




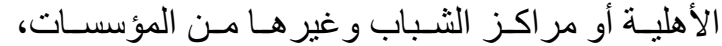
لزيادة توعية الأسر الريفية بأهمية تعليم البنات و أهمية الهية ت تلظيم الأسرة.

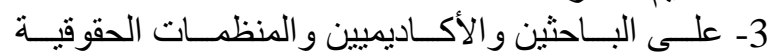

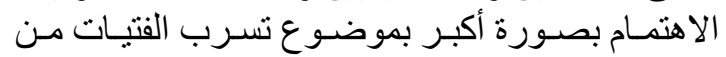

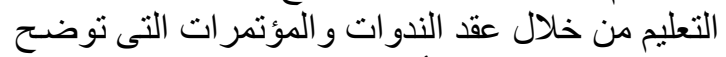

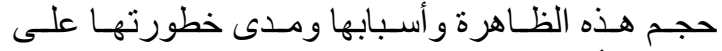
المجتمع أفرادًا وجماعات.

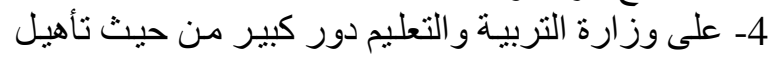

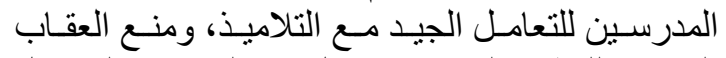

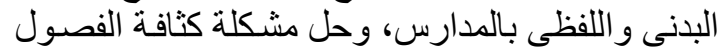
بالمدارس، وضرورة الاهتمام بالأنشطة المدرسية.
تعليمًا كلمـا كان أكثر إدر اكًا للآثنار النفسية المترتبـة على النى ظاهرة تسرب الفتيات من التعليه.

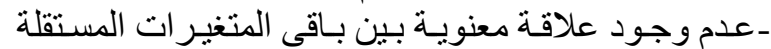

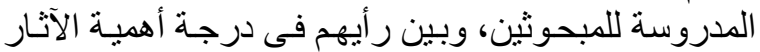

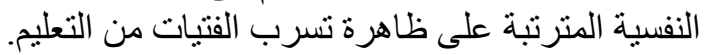

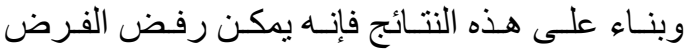

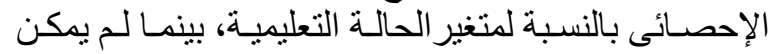

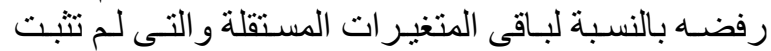

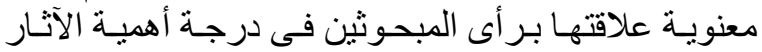

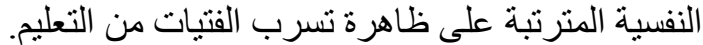

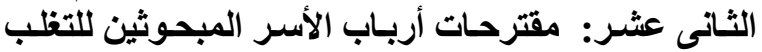
على ظاهرة تسرب الفتيات من التعليم

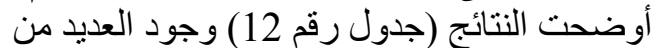

المقترحات من جانب أرباب الأسر المبحوثين للتغلب على العى

\begin{tabular}{|c|c|c|c|c|}
\hline الترتيب & $\%$ & 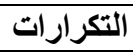 & المقترحات & b \\
\hline 1 & 86.4 & 121 & زيادة الدعم المادى لأسر المتسربين & 1 \\
\hline 2 & 77.8 & 109 & تقليم مكافآت مالية للأسر التى توافق على عودة البنت للمدرسة & 2 \\
\hline 3 & 69.3 & 97 & زيادة توعية الأسر الريفية بأهمية تنظيم الأسرة & 3 \\
\hline 3 مكرر & 69.3 & 97 & زيادة توعية الأسر الريفية بأهمية التعليم بالنسبة للبنات & 4 \\
\hline 4 & 56.4 & 79 & تطوير المدارس وزيادة أعدادها لحل مشكلة الكثافة & 5 \\
\hline 5 & 41.4 & 58 & منع العقاب البذنى واللفظى فى المدارس & 6 \\
\hline
\end{tabular}

6.املة (المراجع

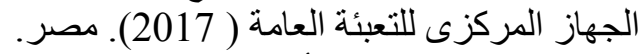

السرور، ناديا (1997 ـأسباب تسربة العادية (2017) الطلبة من الجنسين

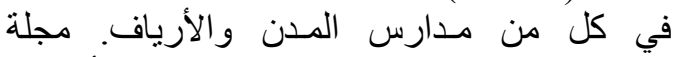
دراسات، عمادة البحث العلمي، الجامعة الأردنية،

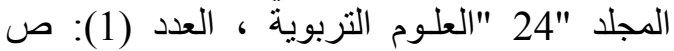
.174-144

السيد ، علي الثخيبي (2002). التسرب كمشكلة اجتماعيـة

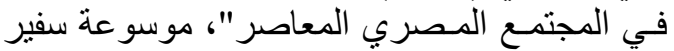

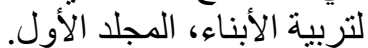
البيلى ، أيمن (2017) الهربة الابناء الهروب من التعليم ظاهرة مصرية،

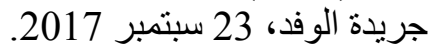

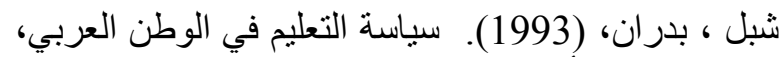

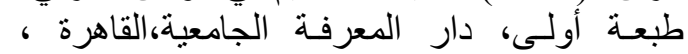
إسماعيل حجي، أحمد (1998). الإدارة التعليمية والإدارة المدرسية، القاهرة"، دار الفكر العربي.

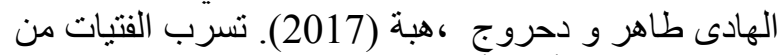
التعليم ...أزمة أمة .. و والطريق إلى المستقبل، الدجلة

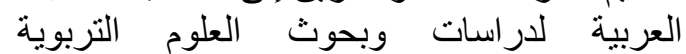
و الإنسانية، العدد 6 ، لورات
ظاهرة تسرب الفتيات من التعليم مرتبة فى الأهمية تنازليا على النحو التالى: جاء فى المرتبة الأولى زيادة الدعم المادى لأسر

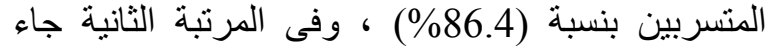

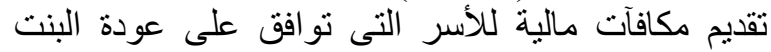

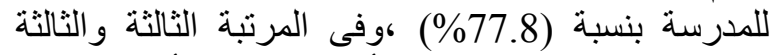
مكرر جاء زيادة توعية الأسر الريفية بأهمية تنظيم الأبية

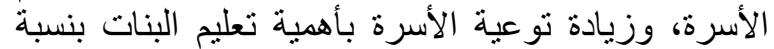

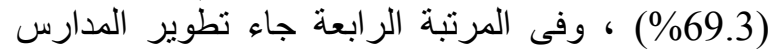

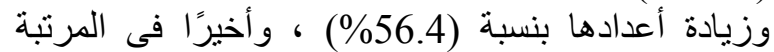

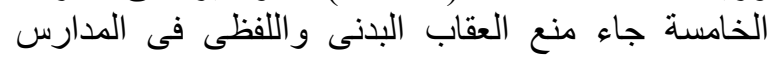
بنسبة (41.4\%).

\section{توصيات البحث} 1- زيادة الدعم المسادى للأسر الريفية الفقيرة خاصـة التى لـى

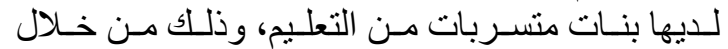

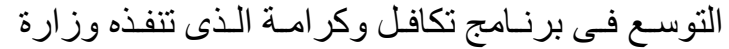

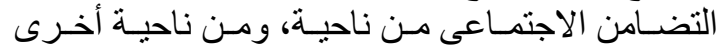
زيادة قيمة الدعم المادى لكل أسرة.

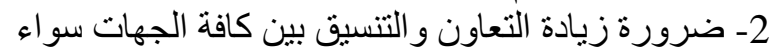
الإعلام أو المدارس أو المؤسسات الدينية أو الجمعيات 